JOEL JOSÉ MEGALE GABRILI

O PAPEL DA SÍLICA MESOPOROSA NANOESTRUTURADA SBA-15 NA ATIVAÇÃO DO INFLAMASSOMA NLRP3

Dissertação apresentada ao Programa de PósGraduação em Imunologia do Instituto de Ciências Biomédicas da Universidade de São Paulo, para obtenção do Título de Mestre em Ciências. 
JOEL JOSÉ MEGALE GABRILI

\section{O PAPEL DA SÍLICA MESOPOROSA NANOESTRUTURADA SBA-15 NA ATIVAÇÃO DO INFLAMASSOMA NLRP3}

Dissertação apresentada ao Programa de PósGraduação em Imunologia do Instituto de Ciências Biomédicas da Universidade de São Paulo, para obtenção do Título de Mestre em Ciências.

Área de concentração: Imunologia

Orientador: Prof. Dr. Osvaldo Augusto Brazil Esteves Sant'Anna

Versão original 
DADOS DE CATALOGAÇÃO NA PUBLICAÇÃO (CIP)

Serviço de Biblioteca e Informação Biomédica do Instituto de Ciências Biomédicas da Universidade de São Paulo

(c) reprodução total

Gabrili, Joel José Megale.

O papel da sílica mesoporosa nanoestruturada SBA-15 na ativação do inflamassoma NLRP3 / Joel José Megale Gabrili. -- São Paulo, 2015.

Orientador: Prof. Dr. Osvaldo Augusto Brazil Esteves Sant'Anna.

Dissertação (Mestrado) - Universidade de São Paulo. Instituto de Ciências Biomédicas. Departamento de Imunologia. Área de concentração: Imunologia. Linha de pesquisa: Novos adjuvantes: sílicas mesoporosas nanoestruturadas.

Versão do título para o inglês: The role of nanostructured mesoporous silica SBA-15 in the NLRP3 inflammasome activation.

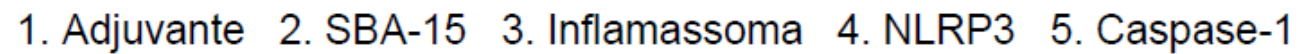
6. Interleucina-1 $\beta$ I. Sant'Anna, Osvaldo Augusto Brazil Esteves II. Universidade de São Paulo. Instituto de Ciências Biomédicas.

Programa de Pós-Graduação em Imunologia III. Título. 
Candidato(a): $\quad$ Joel José Megale Gabrili.

Título da Dissertação: $\quad$ O papel da silica mesoporosa nanoestruturada SBA-15 na ativação do inflamassoma NLRP3.

Orientador(a): $\quad$ Prof. Dr. Osvaldo Augusto Brazil Esteves Sant'Anna.

A Comissão Julgadora dos trabalhos de Defesa da Dissertação de Mestrado, em sessão pública realizada a .................., considerou
( ) Aprovado(a)
( ) Reprovado(a)

Examinador(a): Assinatura:

Nome:

Instituição:

Examinador(a): Assinatura:

Nome:

Instituição:

Presidente: Assinatura:

Nome:

Instituição: 


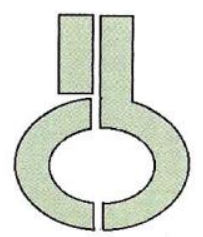

\section{Certificado}

Certificamos que o protocolo registrado sob no $\mathbf{3 4}$ nas fls. $\mathbf{1 7}$ do livro $\mathbf{0 3}$ para uso de animais em experimentação, sob a responsabilidade do $\operatorname{Prof}(a) \operatorname{Dr}(a)$ Osvaldo Augusto Brazil Esteves Sant'Anna, Coordenador (a) da Linha de pesquisa "O Papel da Sílica Mesoporosa Nanoestruturada SBA-15 na Ativação de Nalp3 Inflamassoma" do qual participam o(s) aluno(s) Joel José Megale Gabrili, está de acordo com os Princípios Éticos de Experimentação Animal adotado pela Sociedade Brasileira de Ciência de Animais de Laboratório (SBCAL) e foi aprovado pela COMISSÃO DE ÉTICA NO USO DE ANIMAIS (CEUA) em 30.06.2014, com validade de 4 anos.

São Paulo, 30 de junho de 2014.

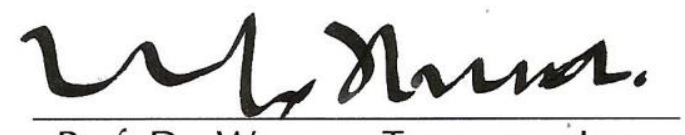

Prof. Dr. WOTHAN TAVARES DE LIMA Coordenador-CEUA- ICB/USP

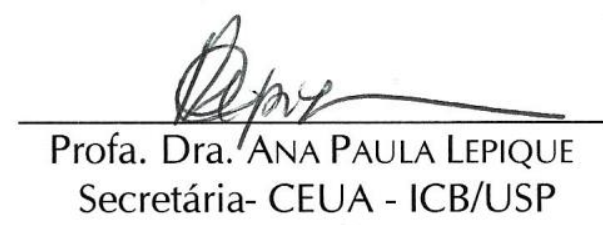




\section{CERTIFICADO}

Certificamos que o projeto intitulado "O papel da Sílica Mesoporosa Nanoestruturada SBA15 na ativação de Nalp3 Inflamassoma", protocolo $n^{\circ} 1219 / 14$, sob a responsabilidade de Osvaldo Augusto Brazil Esteves Sant'Anna e Joel José Megale Gabrili - que envolve a criação e/ou utilização de animais pertencentes ao filo Chordata, subfilo Vertebrata (exceto o homem), para fins de pesquisa científica - está de acordo com os preceitos da Lei $n^{\circ} 11.794$, de 8 de outubro de 2008, do Decreto 6.899, de 15 de julho de 2009 e de normas complementares, bem como está de acordo com os Princípios Éticos na Experimentação Animal adotado pelo Colégio Brasileiro de Experimentação Animal (COBEA), e foi aprovado pela COMISSÃO DE ÉTICA NO USO DE ANIMAIS DO INSTITUTO BUTANTAN (CEUAIB) em reunião de 19/02/2014.

This is to certify that the proposal "The role of nanostructured mesoporous silica SBA-15 in the activation of Nalp3 inflammasome", protocol $n^{0} 1219 / 14$, under the responsibility of Osvaldo Augusto Brazil Esteves Sant'Anna and Joel José Megale Gabrili, - which involves the breeding and/or use of animals belonging to phylum Chordata, subphylum Vertebrata (except human beings) - has been reviewed by the Institute Butantan Animal Care and Use Committee and approved in 2/19/2014. This proposal is in accordance with standards outlined by Brazilian laws for use of experimental animals, and with ethical principles adopted by the Brazilian College of Animal Experimentation.

\begin{tabular}{|c|c|}
\hline $\begin{array}{c}\text { Vigência do Projeto: } \\
03 / 2014-12 / 2015\end{array}$ & $\mathbf{N}^{\circ}$ de animais/espécie \\
\hline Laboratório de Imunoquímica & 120 camundongos C57BL/6 - 18g (M) \\
\cline { 2 - 2 } &
\end{tabular}

São Paulo, 20 de fevereiro de 2014

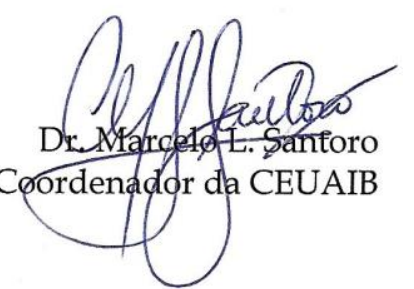


A minha mãe, Magaly,

e minha esposa, Ângela, dois pilares da minha vida. 


\section{AGRADECIMENTOS}

Agradeço primeiramente a Deus, por me dar forças, e permitir que eu consiga concluir um curso de mestrado no departamento de imunologia da Universidade de São Paulo (USP).

Ao meu orientador, Dr. Osvaldo Sant'Anna, por confiar em mim, e me dar à oportunidade de realizar um sonho que estava tão distante.

A Dra. Denise Tambourgi, por abrir as portas do seu laboratório e me incentivar a continuar, e também por me ajudar com a conclusão deste trabalho.

A Dra. Maria Regina D'Imperio Lima, por ceder a cultura de células L929. E sua aluna de doutorado, Rosana Moreira Pereira, pelo auxilio na diferenciação dos macrófagos.

À banca de qualificação, Dra. Karina Bortoluci, Dr. Anderson Sá-Nunes e Karina Scaramuzzi, pelas correções e conselhos passados, e também por abrirem meus olhos para o andamento deste projeto.

A minha mãe, Magaly Megale, guerreira, amorosa, linda e maravilhosa que sempre confiou nas minhas capacidades, e também ao meu "paidrasto", Nelson Rodrigues, que desde minha infância estava ao meu lado, dando todo o apoio possível. Amo vocês.

A minha esposa, Ângela Alice Amadeu Megale, a grande culpada por estar onde estou. Uma pessoa maravilhosa, compreensiva, carinhosa e muito competente. Ao seu lado quero passar o resto da minha vida, e colocar no mundo crianças que espero que sejam iguais a mãe. E também a minha nova família, "Eduardo", Josefa, Joely, "Cris", Yasmin, Larissa, "Cabana", Ana e Mateus, tenho muito orgulho de fazer parte desta família.

Aos meus irmãos, Cristiany Megale Gabrili, Walace Gabrili Neto e Nelson Megale Rodrigues, os quais tive e tenho o prazer de conviver em muitos momentos bons, e também em outros momentos, não tão bons assim. Amo vocês.

Ao meu cunhado, Marcelo, e sobrinho, "Marcelinho", pelo prazer de sermos uma família. Um abraço.

A minha avó Maria Aparecida Moreira Megale, que me aguentava em todas as férias escolares da minha infância, não devia ser fácil, mas me ensinou muito. Sinto falta desses dias, te amo minha avó. Também ao meu avô José Megale (in memoriam), saudades.

Agradeço também ao meu ausente pai, Walvi Aparecido Gabrili, que apesar de a vida nos distanciar cada vez mais, sinto um enorme carinho, apreço, paixão, um fogo que vem de dentro, nas poucas oportunidades em que estivemos juntos.

Aos primos-irmãos "Megales", André, Cassio, Denis, Erick, Giuliano e Guilherme, pelos grandes momentos já vividos.

A Maria Eni do Sacramento Santos, "criatura" que me ajudou tanto em diferentes momentos. Muito obrigado, Eni. 
Ao professor Wilmar Dias da Silva, que admiro muito profissionalmente e principalmente como pessoa. Não tenho palavras para expressar o quanto fico grato em ouvir suas histórias profissionais e de vida.

Aos pesquisadores do Laboratório de Imunoquímica, Dra. Carla Cristina Squaiella Baptistão, Fábio Carlos Magnoli, Dra. Fernanda Portaro, Dra. Giselle Pidde Queiroz e Dr. Jorge M. Ferreira Jr, pessoas com quem tive o prazer de conviver durante o desenvolvimento do meu projeto.

Aos funcionários do Laboratório de Imunoquímica, Alécio, Ana Cláudia, Ana freire, Cinthya, Elaine, Guilherme, Lia, "Marcinha”, Osmair, Ricardo, Rosana, "Seu Ramos" e Sirlene, por fazerem deste local de trabalho uma referência quando comparado com outros laboratórios que tive a oportunidade de conhecer.

Aos alunos, Alexandre, Bruno, Carol, Dani Cajado, Dani Myamoto, Estevan, Felipe França, Felipe Guidolin, Jefferson, Lígia, Mariana, Marrie, Roberto, Verônica e Vivian, por fazer o nosso dia a dia cada vez mais alegre.

Aos pós-doutorandos Ana Tung, Aurélio, Daniel, Isadora e Priscila, pela convivência e auxilio sempre que necessário. Agradecimento especial a Priscila, por toda ajuda na parte de analise estatística.

Ao amigo "Fabinho", pelas varias horas em que conversamos sobre futebol, e também por me suportar, apesar das minhas brincadeiras. Um abraço, meu amigo.

Aos amigos Alécio, Guilherme, Guidolin e "Seu Ramos", que nossos almoços no piratas sejam sempre refeitos. Um abraço a todos.

Ao prof. Niels Olsen Saraiva Câmara, por me deixar cursar, como ouvinte, a disciplina de imunologia. Tenho certeza que sem essa etapa de preparação, nunca teria ingressado no departamento. Muito obrigado.

Aos amigos-irmãos, "Bonfa", "Cadu", Caio, "Dedão", Diego, "Gordinho", Luiz e Tony, pessoas que convivi e pretendo conviver pelo resto da vida.

Ao prof. Silas Lobo, uma pessoa maravilhosa, que me deu muitas oportunidades, e a partir destas, me fez sonhar em um dia ser professor. Muito obrigado meu ex-professor, ex-chefe e eterno amigo.

A Dra. Gabriela Tanaka, por me ensinar a fazer meus primeiros géis e western blotting, e também pela troca de ideias que, com certeza, acrescentaram muito no meu desenvolvimento.

A Dra. Marcia Carvalho de Abreu Fantini, pelas trocas de ideias e, principalmente, por me ceder os trabalhos dos seus alunos: Francisco Mariano Neto e Paulo Ricardo de Abreu Furtado Garcia, que me fizeram compreender, finalmente, a síntese da SBA-15.

A Carolina Pereira Liauw Rodrigues, pelos esclarecimentos, em todas as horas que precisei comprar materiais e reagentes para este projeto. 
A Universidade de São Paulo, em especial ao Hospital Universitário, pelo serviço prestado em um momento tão difícil.

Ao Laboratório Cristália, pela parceria e apoio fundamental para o desenvolvimento de estudos com a SBA-15.

A CAPES, pela bolsa de mestrado, FAPESP, INCT em Toxinas, CeTICS e CNPQ, pelo apoio financeiro. 
Eu calço é 37

Meu pai me dá 36

Dói, mas no dia seguinte Aperto meu pé outra vez 


\section{RESUMO}

GABRILI, J. J. M. O papel da sílica mesoporosa nanoestruturada SBA-15 na ativação do inflamassoma nlrp3. 2015. 59 f. Dissertação (Mestrado em Imunologia) - Instituto de Ciências Biomédicas, Universidade de São Paulo, São Paulo, 2015.

A SBA-15 é constituída por partículas de dióxido de silício $\left(\mathrm{SiO}_{2}\right)$ com estrutura porosa altamente organizada, propriedades físico-químicas que apresentam grande potencial de aplicação em diferentes áreas, despertando interesse na comunidade científica e segmentos tecnológicos. Apesar de existirem vários estudos utilizando sílicas como veículos para diferentes substâncias, não havia ainda nenhum relato sobre a utilização destes materiais como adjuvante. Foi então, que se iniciou no Laboratório de Imunoquímica do Instituto Butantan, o primeiro estudo sobre a possibilidade da utilização da SBA-15 como adjuvante e sobre a sua capacidade de carrear e liberar diferentes antígenos às células imunocompetentes, intensificando a resposta imunológica. Embora já tenha sido comprovada a ação adjuvante da SBA-15, induzindo aumento nos títulos de anticorpos em imunizações contra antígenos de naturezas distintas, em diferentes linhagens de animais, por diferentes vias de administração, pouco se sabe sobre o seu mecanismo molecular de ação que leva a modulação positiva da resposta imunológica. Trabalhos realizados por diferentes autores apontam a via do inflamassoma Nalp3 como responsável pela atividade imunoestimuladora dos adjuvantes de alumínio. Outros relatos afirmam que certas partículas de sílica $\left(\mathrm{SiO}_{2}\right)$ ativam o inflamassoma Nalp3. Com o intuito de avaliar essa ativação, foram utilizados macrófagos peritoneais (MP) e diferenciados da medula óssea (MDMO) de camundongos C57BL/6, mantidos em cultura sobre estímulos da SBA-15 ou agonistas de NLRP3, na presença ou não de LPS e Z-VADFMK. Após 24 horas, os sobrenadantes foram coletados para a análise da produção de IL-1 $\beta$ por ELISA. Em MP, a SBA-15 foi capaz de induzir a produção de IL-1 $\beta$ a níveis semelhantes quando comparado com o Nano-SiO2, sugerindo a ativação do inflamassoma e consequentemente da caspase-1, essencial para a secreção desta citocina. Ainda, foi observado que a ativação frente ao estímulo de SBA-15 ocorre de uma forma dependente da concentração, sendo possível detectar níveis mais elevados de IL-1 $\beta$ no sobrenadante de cultura quando adicionado doses crescentes desta sílica. Também foi detectado IL-1 $\beta$ nos sobrenadantes de MDMO, a níveis mais elevados, quando as células recebem o estímulo da SBA-15 comparando com o Alum. Para avaliar o envolvimento da caspase-1, nos resultados obtidos com a SBA-15, os MDMO foram estimulados com sílica na presença do inibidor de caspase-1 Z-VAD-FMK $(20 \mu \mathrm{M})$, e como esperado, a produção de IL-1 $\beta$ foi restaurada para o seu nível basal. Além disso, foi visto que a SBA-15 não induz a produção de IL-6, confirmando que essa sílica está envolvida na via do inflamassoma e não em outras vias, como por exemplo, NF-кB. A ativação do inflamassoma, por estímulos da SBA-15, parece ser parcialmente dependente da fagocitose e da produção das espécies reativas do oxigênio.

Palavras-chave: Adjuvante. SBA-15. Inflamassoma. NLRP3. Caspase-1. Interleucina-1 $\beta$. Macrófagos. 


\begin{abstract}
GABRILI, J. J. M. The role of nanostructured mesoporous silica SBA-15 in the nlrp3 inflammasome activation. 2015. 59 p. Masters thesis (Immunology) - Instituto de Ciências Biomédicas, Universidade de São Paulo, São Paulo, 2015.

The SBA-15 is composed by silicon dioxide particles ( $\mathrm{SiO} 2)$ with highly organized porous structure, physicochemical properties that have great application potential in different areas, arousing interest in the scientific community and technological segments. Despite many studies using silica as vehicles for different substances, there was still no report about the use of these materials as adjuvant. It was then that began in Immunochemistry Laboratory of the Butantan Institute, the first study on the possibility of using SBA-15 as an adjuvant and on their ability to deliver and release different antigens to immunocompetent cells, enhancing the immune response. Although it has been proven adjuvant action of SBA-15, inducing increase in antibody titers in immunizations with antigens of different natures, in different strains of animals and by different routes of administration, little is known about its molecular mechanism of action it leads to positive modulation of the immune response. Work carried out by different authors point out the path of NALP3 inflammasome as responsible for the immunostimulatory activity of aluminum adjuvants. Other reports state that certain particles of silica $(\mathrm{SiO} 2)$ activate NALP3 inflammasome. In order to evaluate this activation, peritoneal and differentiated bone marrow macrophages from C57BL/6 mice were used, maintained in culture for stimulation of SBA-15 or NLRP3 agonists in the presence or not of LPS and Z-VAD-FMK. After 24 hours, the supernatants were collected for analysis of IL-1 $\beta$ production by ELISA. In peritoneal macrophages, SBA-15 was able to induce the production of IL-1 $\beta$ in similar levels as compared with Nano-SiO2, suggesting the inflammasome activation and hence caspase- 1 that is essential for the secretion of this cytokine. Still, it was observed that the activation stimulus by SBA-15 occurs in a concentration dependent manner, being possible to detect increased levels of IL-1 $\beta$ in the culture supernatant when added increasing doses of this silica. Also IL-1 $\beta$ was detected in the supernatants of bone marrow-derived macrophages at higher levels when the cells receive stimulation of SBA-15 compared to the alum. To assess the involvement of caspase-1, in the results obtained with SBA-15, the bone marrow-derived macrophages were stimulated with silica in the presence of the caspase-1 inhibitor Z-VAD-FMK $(20 \mu \mathrm{M})$, and as expected, the production of IL $-1 \beta$ was restored to its baseline level. In addition, it was seen that the SBA15 does not induce IL-6 production, confirming that silica is involved in inflammasome pathway and not in other ways, for example, in NF-kB pathway. The inflammasoma activation, by stimuli of SBA-15, appears to be partly dependent of phagocytosis and reactive oxygen species production.
\end{abstract}

Keywords: Adjuvant. SBA-15. Inflammasome. NLRP3. Caspase-1. Interleukin-1 $\beta$. Macrophages. 


\section{LISTA DE ILUSTRAÇÕES}

Figura 1 - Estrutura dos membros da família M41S...................................................... 21

Figura 2 - Estrutura da sílica mesoporosa ordenada SBA-15 ............................................ 21

Figura 3 - Sílica mesoporosa ordenada SBA-15 contendo poros interligados ....................... 22

Figura 4 - Diagrama esquemático demonstrando a síntese da SBA-15 ................................. 23

Figura 5 - Receptores de reconhecimento de padrões (PRRs) ............................................. 25

Figura 6 - Esquema das proteínas da família dos receptores do tipo NOD ............................ 27

Figura 7 - Representação esquemática de NLRP3, NLRC4, ASC e caspase-1 ....................... 30

Figura 8 - Viabilidade de macrófagos peritoneais tratados com SBA-15, Nano-SiO2 e

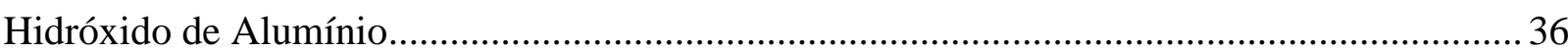

Figura 9 - Análise da produção de IL-1 $\beta$ por macrófagos peritoneais estimulados com Nano-

$\mathrm{SiO}_{2}$ ou SBA-15

Figura 10 - Análise da produção de IL-1 $\beta$ por macrófagos peritoneais estimulados com SBA-

15 . 38

Figura 11 - Análise da produção de IL-1 $\beta$ por macrófagos derivados da medula óssea estimulados com SBA-15, Nano-SiO2 ou Hidróxido de Alumínio

Figura 12 - Análise da produção de IL-1 $\beta$ por macrófagos derivados da medula óssea estimulados com SBA-15e Z-VAD-FMK

Figura 13 - Análise da produção das citocinas IL-6 e IL-1 $\beta$ por macrófagos derivados da medula óssea estimulados com LPS, SBA-15 e Z-VAD-FMK

Figura 14 - Análise da produção de IL-1 $\beta$ por macrófagos peritoneais estimulados com SBA15 , ATP e citocalasina D

Figura 15 - Análise da produção de IL-1 $\beta$ por macrófagos peritoneais estimulados com SBA15 e cloreto de difenileno-iodônio (DPI).

Figura 16 - Mecanismo de interação da SBA-15 com macrófagos 50 


\section{LISTA DE ABREVIATURAS E SIGLAS}

acLP - Acylated Lipopeptides

AIF - Adjuvante incompleto de Freund

AIM2 - Absent in Melanoma 2

ALUM - Hidróxido de Alumínio

APAF - Apoptotic Protease Activating Factor

APCs - Células apresentadoras de antígenos

ASC - Apoptosis-associated Speck-like protein containg a CARD

BIR - Baculovirus IAP repeat

BSA - Bovine Serum Albumin

CARD - Caspase Activation and Recruitment Domain

CLRs - C-type Lectin Receptors

DAMPs - Damage-Associated Molecular Patterns

DCs - Células dendríticas

DL50 - Dose letal mediana

DMEM - Dulbecco's Modified Eagle Medium

DOTAP - dioleoyl trimethylammonium propane

DPI - Diphenyleneiodonium chloride

ELISA - Enzyme-linked Immunosorbent Assay

EROs - Espécies reativas do oxigênio

FDA - Food and drugs administration

HBsAG - Antígeno de superfície do vírus da hepatite B

IgG - Imunoglobulina $\mathrm{G}$

IL-1 $\beta$ - Interleukin-1 $\beta$

IL-6 - Interleukin-6

IL-18 - Interleukin-18

IRFs - IFN-responsive factors

IUPAC - International Union of Pure and Applied Chemistry

LPS - Lipopolissacarídeo

LRR - Leucine-rich Repeat

MAL/TIRAP - MyD88-adaptor like/TIR-associated protein

MARCO - Macrophage Receptor with Collagenous Structure

MCM-41 - Mobil Composition of Matter-41 
MCM-48 - Mobil Composition of Matter-48

MCM-50 - Mobil Composition of Matter-50

M-CSF - Macrophage Colony-Stimulating Factor

MDMO - Macrófagos derivados da medula óssea

MDP - Muramil dipeptídeo

meso-DAP - $\gamma$-D-glutamyl-meso-diaminopimelic acid

MP - Macrófagos peritoneais

MSU - Monosodium Urate

MTT - 3-(4, 5-dimethylthiazol-2-yl)-2,5-di-phenyltetrazolium bromide

MyD88 - Myeloid Differentiation factor 88

NACHT - Domain present in NAIP, CIITA, HET-E, TP-1

NADPH - Nicotinamide Adenine Dinucleotide Phosphate

Nano-SiO2 - SiO2 nanoparticles

NBD - Nucleotide-binding Domain

$\mathrm{NF}-\kappa \mathrm{B}-$ Nuclear Factor $\kappa \mathrm{B}$

NLRBs - NLRs family, BIR domain containing

NLRCs - NLRs family, CARD domain containing

NLRPs: NLRs family, pyrin domain containing

NLRs - Nod-like Receptors

PAMPs - Pathogen-Associated Molecular Patterns

PEO - Poly(Ethylene-Oxide)

PPO - Poly(Propylene-Oxide)

PRRs - Pattern Recognition Receptors

PYD - Pyrin domain

PYHIN - Pyrin and HIN Domain-containing Protein

RLRs - RIG-I-like Receptors

SARM - Sterile $\alpha$ - andarmadillo-motif containing protein

SBA-15 - Santa Barbara Amorphous-15

SFB - Soro Fetal Bovino

$\mathrm{SiO} 2$ - Dióxido de silício

SR-A - Class A Scavenger Receptor

T3SS - Sistema de secreção do tipo III

T4SS - Sistema de secreção do tipo IV

TEOS - Tetraetilortosilicato 
TLRs - Toll-like receptors

TRAM - Toll-receptor-associated molecule

Z-VAD-FMK - carbobenzoxy-valyl-alanyl-aspartyl-[O-methyl]-fluoromethylketone 


\section{SUMÁRIO}

1 INTRODUÇÃ

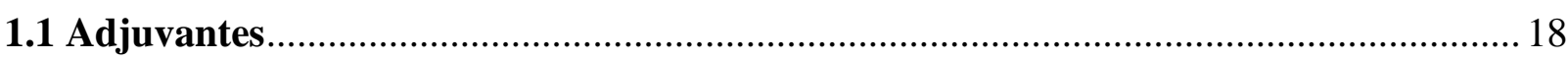

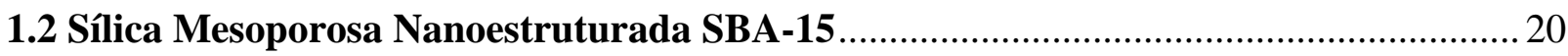

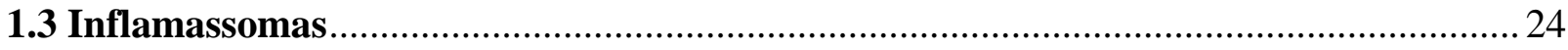

2 OBJETIVOS

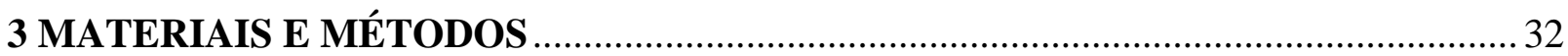

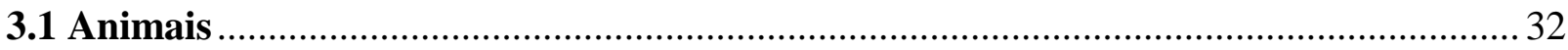

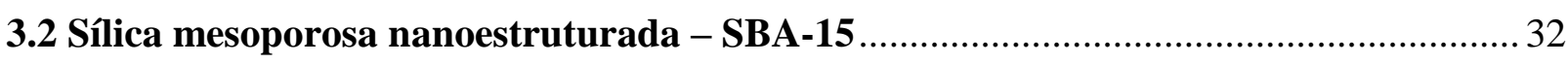

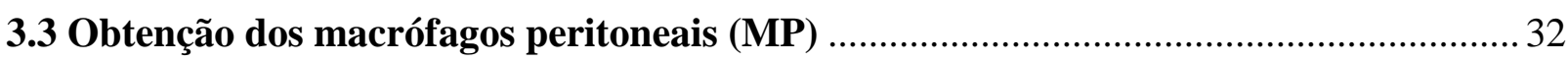

3.4 Obtenção de M-CSF do sobrenadante da cultura de células L929 ............................... 33

3.5 Obtenção dos macrófagos derivados da medula óssea (MDMO) .................................. 33

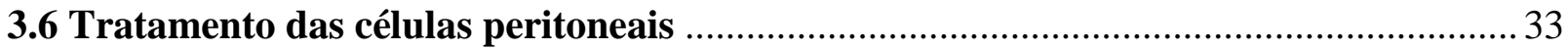

3.7 Tratamento dos macrófagos derivados da medula óssea............................................. 34

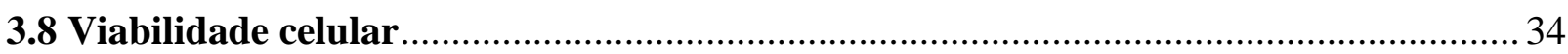

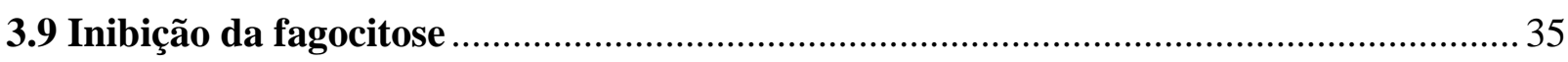

3.10 Inibição da produção das espécies reativas do oxigênio (EROs) ................................ 35

3.11 Detecção de citocinas nos sobrenadantes das culturas............................................... 35

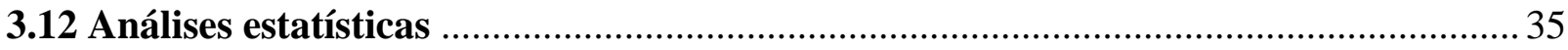

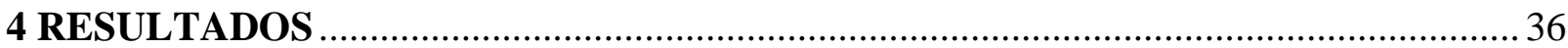

4.1 SBA-15 não é tóxica para macrófagos peritoneais ........................................................ 36

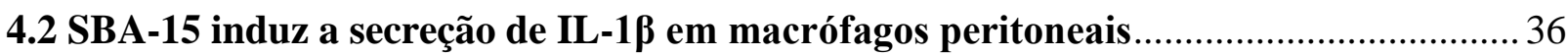

4.3 SBA-15 induz a secreção de IL-1ß, dependente de caspase-1, em macrófagos

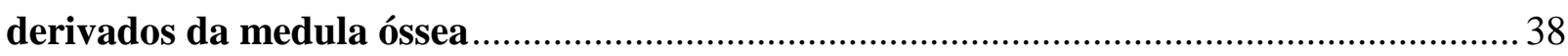

4.4 SBA-15 não induz a secreção de IL-6 em macrófagos derivados da medula óssea ....... 40

4.5 O papel da fagocitose na secreção de IL-1ß induzida por SBA-15 …......................... 41

4.6 A produção das espécies reativas do oxigênio (EROs) está envolvida na secreção de

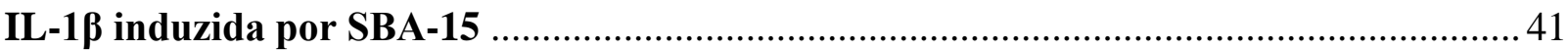

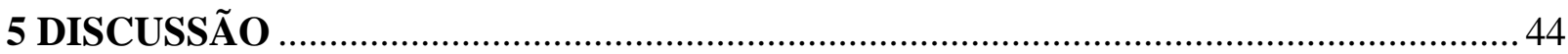

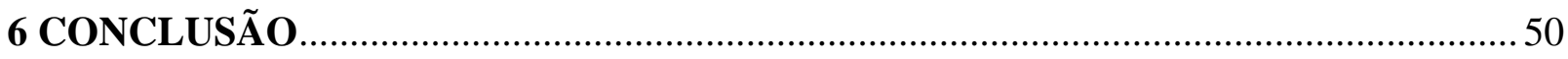

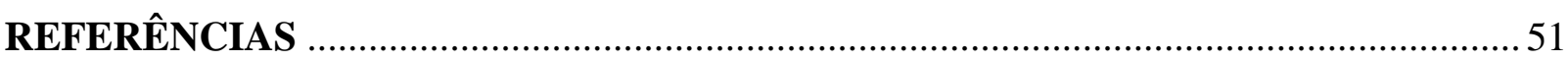




\section{INTRODUÇÃO}

\subsection{Adjuvantes}

Desde as primeiras tentativas para aumentar significativamente as respostas imunológicas contra agentes infecciosos, pesquisadores tentam identificar aditivos que sejam úteis para melhorar a resposta imune contra os antígenos co-inoculados. Esses aditivos que favorecem a resposta são conhecidos como adjuvantes (OTT; NEST, 2007).

Adjuvantes são utilizados para potencializar a resposta imunológica contra antígenos há mais de noventa anos (GUPTA et al., 1993). O termo adjuvante tem origem do latim, da palavra adjuvare, que significa ajudar ou melhorar (BRAGA, 2011; COX; COULTER, 1997; GUPTA et al., 1993; GUPTA; SIBER, 1995; PETROVSKY; AGUILAR, 2004; SCARAMUZZI, 2009). Um dos primeiros relatos de uso de substâncias com potencial adjuvante foi feito em 1916, quando Le Moignic e Pinoy utilizaram uma emulsão em água, vaselina e Salmonella typhimurium inativada, para imunizar camundongos, e observaram o aumento na resposta de anticorpos (AUCOUTURIER; DUPUIS; GANNE, 2001; JANSEN et al., 2005; SCARAMUZZI, 2009).

Qualquer composto natural ou sintético que aumente a resposta imune é considerado um adjuvante, e desde o início de sua utilização, diversas substâncias foram testadas; por exemplo, observou-se que havia uma melhora na resposta humoral contra a toxina diftérica em cavalos imunizados com essa toxina e pus (KAEBERLE, $1986^{1}$ apud RESENDE et al., 2004). Na década de 20, Ramon utilizou desde óleo de amido, tapioca, saponinas, lectina, agar e até mesmo farinha de rosca (migalhas de pão) como adjuvante e obteve bons resultados contra as toxinas diftéricas e tetânicas. Tais fatos mostram que o estudo dos efeitos adjuvantes de certas substâncias eram realizados de maneira totalmente empírica (RAMOM, $1926^{2}$ apud OTT; NEST, 2007).

Os adjuvantes são necessários para tornar vacinas de baixa imunogenicidade mais imunogênicas, reduzir o número de imunizações para indução de proteção ou a quantidade de antígeno utilizado, liberar lentamente os antígenos no organismo, melhorar a eficácia da

\footnotetext{
${ }^{1}$ Kaeberle ML. Function of carriers and adjuvants in induction of immune responses. In: Kaeberle ML, Nervig RM, Gough PM, eds. Advances in Carries and adjuvants for veterinary biologics. New York: University press; 1986.

${ }^{2}$ Ramon, G. Procédures pour acroite la production des antitoxines. Ann Inst Pasteur Paris, v. 40, p. 1-10, 1926.
} 
vacinação em recém-nascidos, idosos ou imunocomprometidos, entre outros (COX; COULTER, 1997; PETROVSKY; AGUILAR, 2004; RESENDE et al., 2004).

Cada substância adjuvante tem seu próprio mecanismo de ação, entretanto, a maioria destes mecanismos permanece desconhecida ou controversa. Tais substâncias podem estimular a imunidade mediada por células, modulando a resposta imunológica para o tipo Th1 ou Th2, induzir inflamação local e aumentar o contato das células com os antígenos e/ou formar um depósito de antígenos, liberando-os aos poucos e assim prolongar sua interação com células apresentadoras de antígenos (APCs) (COX; COULTER, 1997; RESENDE et al., 2004).

As principais limitações para o uso de novos sistemas adjuvantes para vacinas humanas giram em torno de questões de segurança. Assim, e diversos adjuvantes já foram avaliados em modelos animais, no entanto, muitos não podem ser utilizados em humanos devido a sua toxicidade. Considerando que os efeitos adversos dos adjuvantes foram reduzidos por meio de pesquisa e desenvolvimento ao longo dos últimos 90 anos, as barreiras de segurança apresentadas por questões regulatórias e de responsabilidade continuam a aumentar. (OTT; NEST, 2007).

O Hidróxido de Alumínio (Alum) é o único adjuvante licenciado pela U. S. Food and Drug Administration (FDA) para utilização em vacinas humanas desde a década de 20, enquanto a Agência Européia de Avaliação de Medicamentos licenciou outros três compostos para utilização em humanos nos últimos 20 anos: MF59, uma emulsão de água em óleo à base de esqualeno utilizado na vacina contra a gripe (FLUAD) em 1997; AS04, uma junção de um análogo de LPS (Monofosforil Lipídio A) e Alum, utilizado na vacina do HBV (Fendrix) em 2005; e a emulsão AS03 de óleo em água, utilizado na vacina pré-pandêmica contra a gripe aviária (Prepandrix) no ano de 2008 (GREGORIO; TRITTO; RAPPUOLI, 2008).

A investigação e o desenvolvimento de adjuvantes de vacinas têm sido um trabalho contínuo por cerca de um século. O desenvolvimento bem sucedido é o resultado do equilíbrio entre segurança e imunogenicidade, entrega e imunoestimulação, simplicidade e complexidade. O fato de, após este longo período de estudos, tão poucos adjuvantes estarem aprovados para vacinas humanas, atesta a dificuldade desta atividade. Parece que estamos no início de uma nova era em que uma variedade de novos adjuvantes estão prestes a serem aprovados (OTT; NEST, 2007). 


\subsection{Sílica Mesoporosa Nanoestruturada SBA-15}

A SBA-15 é constituída por partículas de dióxido de silício $\left(\mathrm{SiO}_{2}\right)$ com estrutura mesoporosa altamente organizada, propriedades físico-químicas que apresentam grande potencial de aplicação em diferentes áreas, despertando interesse na comunidade científica e segmentos tecnológicos (CARVALHO, 2007, 2010; KRESGE et al., 1992; SCARAMUZZI, 2009, 2013; YANG; COOMBS; OZIN, 1997).

De acordo com a International Union of Pure and Applied Chemistry (IUPAC), materiais mesoporosos são aqueles que apresentem poros com diâmetro entre 2-50 nm. Materiais cujo diâmetro dos poros é maior ou menor que estes, são chamados de macroporosos e microporosos, respectivamente (EVERETT, 1972).

Materiais mesoporosos são preferidos devido a sua estrutura altamente ordenada, além de uma elevada área superficial, o que permite a difusão e a adsorção de moléculas maiores para amplas aplicações, diferentemente de materiais com microestrutura que limita a sua utilização apenas para separação e catálise química (FEDEYKO; VLACHOS; LOBO, 2006; RAHMAT; ABDULLAH; MOHAMED, 2010).

Esses materiais são amplamente utilizados como catalisadores (ABDALLA; LI; TUFAIL, 2009; TAGUCHI; SCHÜTH, 2005), biossensores (XU et al., 2009), na área de biocombustíveis (OOI; BHATIA, 2007), absorção (CHANG et al., 2008), membrana de separação (ZORNOZA et al., 2009) e controle de entrega de drogas (PASQUA et al., 2009).

Sílicas mesoporosas foram sintetizadas pela primeira vez em 1990 por um grupo de pesquisadores da Universidade de Waseda, Tokio (YANAGISAWA et al., 1990). Após dois anos, foram produzidos pela Mobil Research and Development Corporation, materiais mesoporosos compostos de silicatos ou aluminossilicatos, os quais foram denominados família M41S (BECK et al., 1992; KRESGE et al.,1992). Nesta família estão inclusos: MCM41, que possui estrutura hexagonal; MCM-48, com estrutura cúbica; e MCM-50 apresentando uma estrutura lamelar (Figura 1) (TAGUCHI; SCHÜTH, 2005). 
Figura 1 - Estrutura dos membros da família M41S

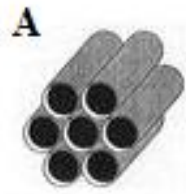

MCM-41

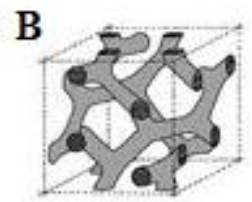

MCM-48

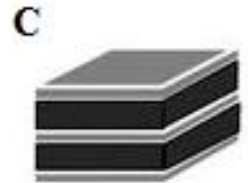

MCM-50

A família de sílicas mesoporosas M41S possui três integrantes com diferentes estruturas: A) MCM-41, estrutura hexagonal; B) MCM-48, estrutura cúbica; C) MCM-50, estrutura lamelar. Adaptado de Kresge e Roth, 2013.

Dentro dessa família o material mais estudado é o MCM-41, no entanto, muitas aplicações práticas desse material ainda estão sendo implementadas por causa de sua baixa estabilidade hidrotérmica, que pode estar relacionada com a espessura das paredes de seus poros, que são relativamente finas, variando de 0,6 e 1,2 nm (GALLIS; LANDRY, 1997; KIM; JUN; RYOO, 1999; SOUZA, 2009).

A SBA-15, descrita por Zhao e colaboradores (1998a) é composta por partículas de $\mathrm{SiO}_{2}$ com estrutura hexagonal (Figura 2), poros altamente ordenados e interligados $(10 \mathrm{~nm})$ (Figura 3), com paredes moderadamente espessas (3,1 a 6,4 nm) que lhe confere uma melhor estabilidade hidrotérmica quando comparado ao MCM-41, além de sua notável estabilidade térmica e mecânica (MATOS et al., 2001; ZHAO et al., 1998a; ZHAO et al., 1998b).

Figura 2 - Estrutura da sílica mesoporosa ordenada SBA-15

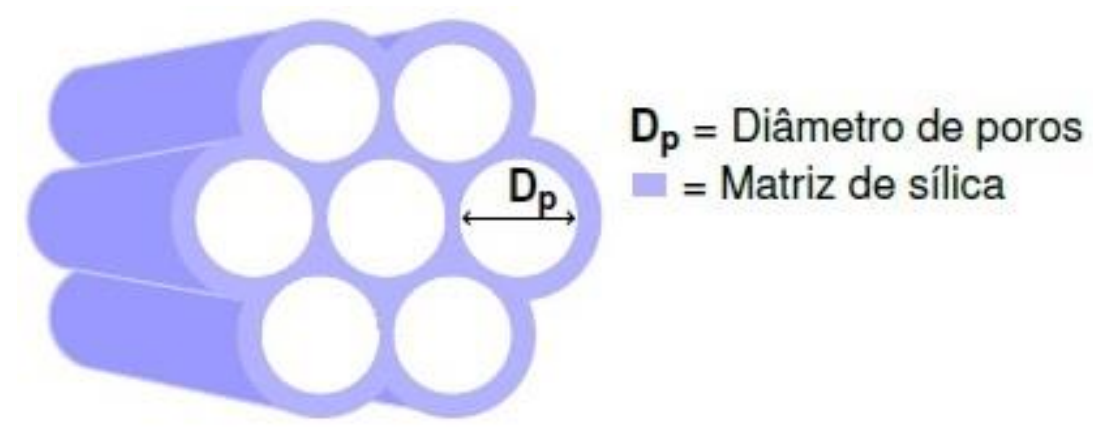

Representação da SBA-15 contendo poros e sua matriz de sílica com estrutura hexagonal. Adaptado de Garcia, 2015. 
Figura 3 - Sílica mesoporosa ordenada SBA-15 contendo poros interligados

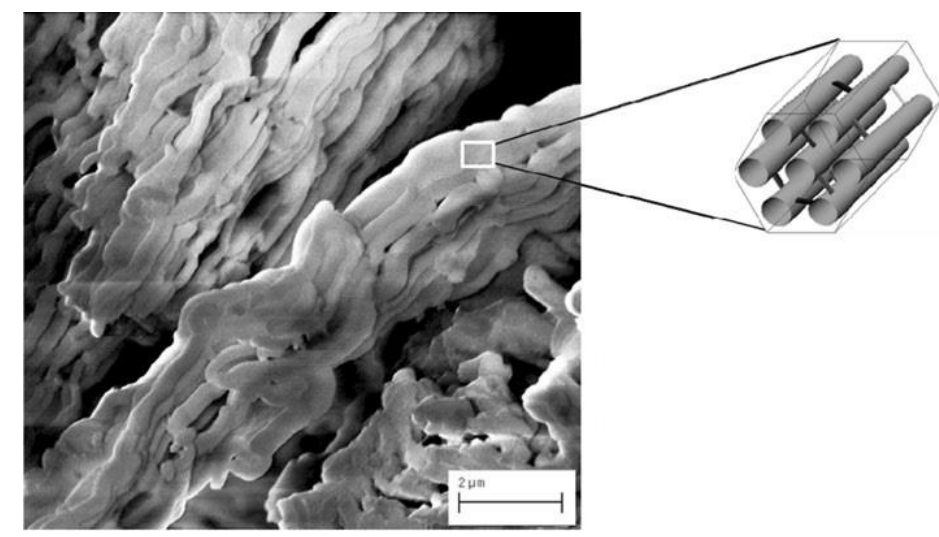

Microscopia eletrônica de varredura da SBA-15 e um modelo esquemático da sua estrutura hexagonal contendo poros interligados. Adaptado de Seftel et al., 2013.

Descoberta na Faculdade da Califórnia em Santa Barbara, de onde origina seu nome, "Santa Barbara Amorphous-15”, esse material é sintetizado em meio ácido, utilizando como agente direcionador de estrutura um copolímero tribloco, o poli(óxido de etileno)-poli(óxido de propileno)-poli(óxido de etileno) $\left(\mathrm{PEO}_{20} \mathrm{PPO}_{70} \mathrm{PEO}_{20}\right)$, que auto agrega-se com espécies de silicatos formando a sílica mesoporosa (ZHAO et al., 1998a; ZHAO et al., 1998b).

A síntese da SBA-15 é caracterizada por ocorrer em meio ácido ( $\mathrm{HCl} 2 \mathrm{M})$, utilizar como surfactante o polímero Pluronic P123 direcionando a sua estrutura hexagonal e o tetraetilortosilicato (TEOS) como fonte de silício. O Pluronic P123 é composto por um bloco hidrofóbico central formado por 70 unidades de PPO e dois blocos hidrofílicos periféricos formados por 20 unidades de PEO. Ao ser solubilizado, os surfactantes se auto-organizam tentando minimizar o contato entre as partes hidrofóbicas das moléculas e a água formando assim micelas esféricas com uma região hidrofóbica interna e uma região hidrofílica externa. Essas micelas se agregam formando estruturas aproximadamente cilíndricas, sobre as quais a sílica vai se aglomerar (Figura 4) (GARCIA, 2015; NETO, 2013).

O próximo passo é a adição da fonte de silício, quando as moléculas de TEOS são incorporadas na porção hidrofóbica das micelas, onde são hidrolisadas, gerando $\mathrm{SiO} 2$ e etanol. O SiO2 se assenta na porção hidrofílica das micelas, dando origem às paredes da SBA15. Após esse processo o material é transferido para uma autoclave que acarreta a organização final da estrutura hexagonal das micelas e também a densificação das paredes. Por fim, o material é calcinado a $540{ }^{\circ} \mathrm{C}$, para a remoção do polímero, dando origem aos microporos e mesoporos (GARCIA, 2015; NETO, 2013).

Quanto à formação dos microporos, a hipótese mais aceita é que eventualmente depois que as moléculas de sílica hidrolisadas se associam com as micelas, partes do polímero podem 
se estender para dentro da matriz de sílica. Após a calcinação, o polímero é retirado deixando os microporos que se prolongam dos mesoporos para a matriz (POLLOCK et al., 2011).

Figura 4 - Diagrama esquemático demonstrando a síntese da SBA-15

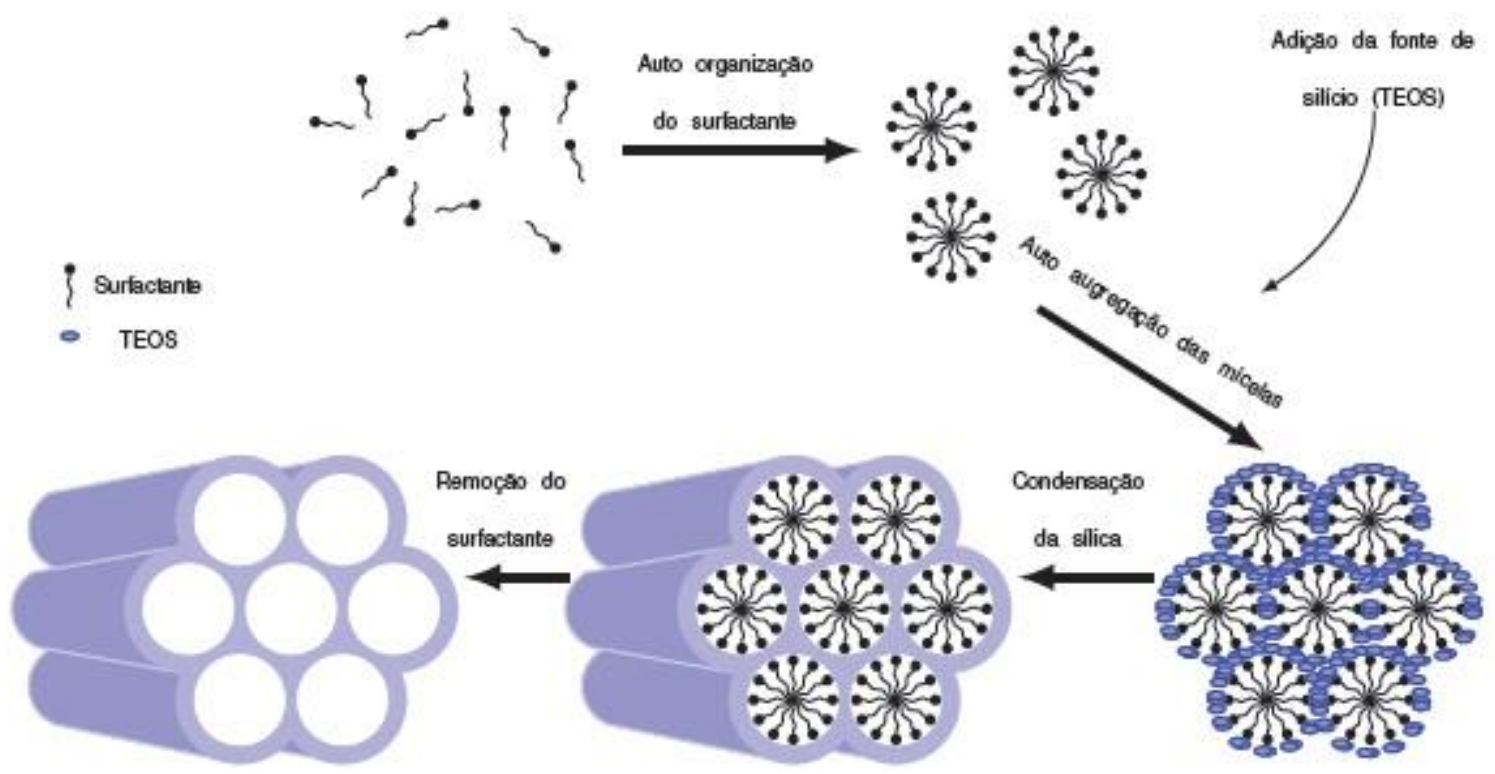

Representação esquemática da síntese da SBA-15. Utilizando o surfactante Pluronic P123 em meio ácido, são formadas micelas que se auto agregam; a fonte de silício (tetraetilortosilicato - TEOS) se deposita sobre as micelas dando origem as paredes da SBA-15; para a remoção do surfactante o material é calcinado a $540{ }^{\circ} \mathrm{C}$, resultando na formação dos microporos e mesoporos (GARCIA, 2015).

Apesar de vários estudos utilizarem sílicas como veículos para diferentes substâncias, não havia nenhum relato da utilização destes materiais como adjuvante. Foi então, que se iniciou no Laboratório de Imunoquímica do Instituto Butantan, o primeiro estudo sobre a possibilidade da utilização da SBA-15 como adjuvante e sobre a sua capacidade de carrear e liberar diferentes antígenos às células imunocompetentes, intensificando a resposta imunológica (CARVALHO, 2007, 2010; SCARAMUZZI, 2009, 2013; SCARAMUZZI et al., 2009).

Pode-se dizer que o primeiro resultado obtido com essa sílica, foi quando se juntou um volume de SBA-15 com um volume igual de uma proteína, sendo que o resultado não foi dois volumes, mas cerca de 1,5, sugerindo assim a ocorrência de adsorção/encapsulação da proteína à sílica (dados não publicados). Ainda, estudos realizados por Mercuri et al. (2006) demonstraram o potencial da SBA-15 em encapsular/adsorver antígenos de natureza distinta, como a Intimina $1 \beta$ (proteína de Escherichia coli) e veneno total de Micrurus ibiboboca, induzindo imunidade efetiva e duradoura em camundongos geneticamente selecionados para a baixa produção de anticorpos (linhagem $\mathrm{L}_{\text {III }}$ - SANT'ANNA et al., 1982) e isogênicos 
(BALB/c), com uma resposta secundária semelhante ou mais elevada quando comparada aos animais imunizados com esses antígenos em hidróxido de alumínio ou adjuvante incompleto de freund (AIF).

No dia 12 de setembro de 2005 foi depositada a Patente: COMPLEXO IMUNOGÊEICO FORMADO POR ANTÍGENOS VACINAIS ENCAPSULADOS POR SÍLICA MESOPOROSA NANOESTRUTURADA, uma parceria com o Laboratório Cristália, recebendo o número PI 0503817-0 e, em setembro de 2007, foi encaminhado para o depósito internacional. No momento atual, esse estudo está sob a proteção das patentes internacionais:

\section{WO 07030901, IN 248654, ZA 2008/02277, KR 1089400 e MX 297263.}

Em 2010, foi verificado que camundongos das linhagens $\mathrm{L}_{\mathrm{III}}$ e $\mathrm{L}_{\mathrm{IVA}}$, maus produtores de anticorpos, imunizados com albumina sérica bovina (BSA) adsorvida em SBA-15, pelas vias intramuscular e oral, produziam títulos de $\mathrm{IgG}$ similares aos animais das linhagens $\mathrm{H}_{\mathrm{III}} \mathrm{e}$ $\mathrm{H}_{\mathrm{IVA}}$, bons produtores. Também foi comprovado que essa sílica não era tóxica para macrófagos em cultura e para os animais imunizados (CARVALHO et al., 2010).

O efeito adjuvante da SBA-15 também foi observado em 2011, utilizando camundongos $\mathrm{BALB} / \mathrm{c}$ imunizados pelas vias oral e subcutânea com a proteína recombinante HBsAg do vírus da hepatite B. Neste foi verificado um aumento nos títulos de anticorpos específicos quando utilizada essa partícula nas formulações vacinais (SCARAMUZZI et al., 2011).

Apesar de comprovado o efeito adjuvante da SBA-15, pelo aumento dos títulos de anticorpos em imunizações contra antígenos de naturezas distintas, em diferentes linhagens de camundongos e por diferentes vias de administração, ainda não se sabe como ela atua no organismo para aumentar a resposta imunológica.

\subsection{Inflamassomas}

O desenvolvimento do sistema imunológico foi uma conquista evolutiva fundamental que permitiu a sobrevivência de organismos contra injurias externas e internas. A partir dos vertebrados mandibulados, a imunidade passou a ser didaticamente separada em inata e adaptativa, as quais interagem constantemente. A imunidade inata é filogeneticamente mais antiga e é a primeira linha de defesa do organismo, capaz de conduzir uma resposta rápida contra um patógeno, mediado por fagócitos, incluindo macrófagos, neutrófilos e células dendríticas (DCs); em contraste, a imunidade adaptativa, a qual depende da interação das células apresentadoras de antígenos profissionais (APCs) com os linfócitos T e B, e uma 
resposta mais refinada do sistema imunológico e pode demorar cerca de 4 a 7 dias para se desenvolver (AKIRA; UEMATSU; TAKEUCHI, 2006; COOPER; ALDER, 2006; MIYAJI et al., 2011).

A imunidade inata reconhece microrganismos por meio de receptores codificados na linhagem germinativa, denominados receptores de reconhecimento de padrões (PRRs), que podem ser expressos na superfície da célula ou em compartimentos intracelulares (Figura 5), enquanto o sistema imune adaptativo, utiliza um grande repertório de receptores rearranjados aleatoriamente na linhagem somática (AKIRA; UEMATSU; TAKEUCHI, 2006; JANEWAY; MEDZHITOV, 2002).

Figura 5 - Receptores de reconhecimento de padrões (PRRs)

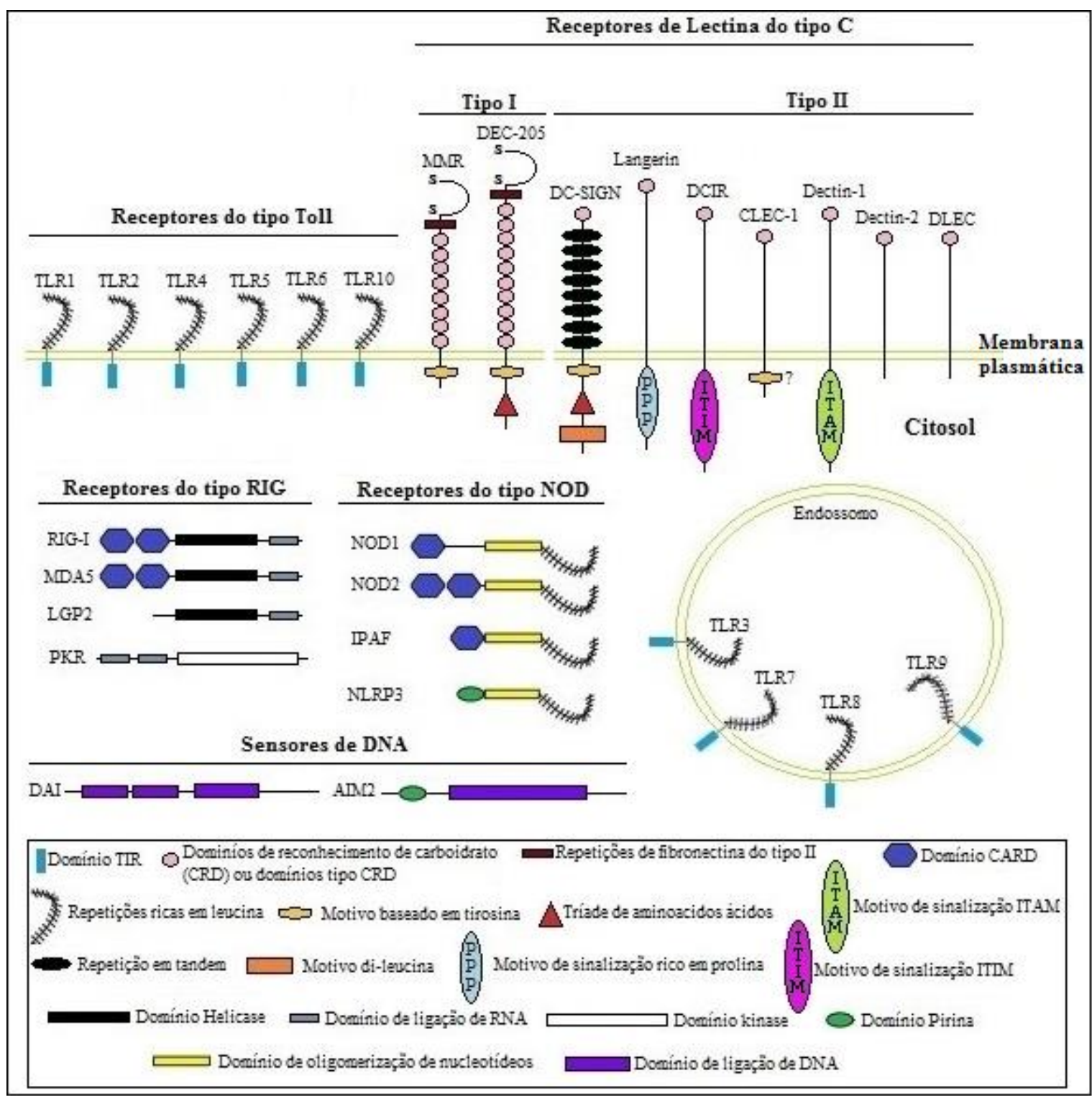

Representação esquemática das principais classes de receptores de reconhecimento de padrões (PRRs) do sistema imune inato. Adaptado de Figdor; Van Kooyk; Adema, 2002; Mogensen, 2009; Miyaji et al., 2011. 
Os alvos de reconhecimento dos PRRs são padrões moleculares frequentemente associados a patógenos (Pathogen associated molecular pattern - PAMP). Essas estruturas moleculares são essenciais para a sobrevivência dos micro-organismos e mutações nessas regiões seriam letais para esses organismos. A conservação destas estruturas faz com que elas sejam compartilhadas por grandes grupos de patógenos e permite que um número limitado de receptores possa reconhecer uma grande variedade de micro-organismos (JANEWAY, 1989; MEDZHITOV; JANEWAY, 1997). No entanto, a imunidade inata não é capaz de reconhecer apenas PAMPs. Um mecanismo descrito por Matzinger (2002), conhecido como o "modelo de perigo" (The DangerModel) sugere a capacidade do sistema imune inato em reconhecer sinais de alarme/perigo provenientes de células danificadas, tais como ácido úrico e efluxo de potássio que foram denominados padrões moleculares associados ao dano ou perigo (DAMPs) (MARTINON; TSCHOPP, 2005; MATZINGER, 2002).

Atualmente, várias classes de PRRs foram identificadas, incluindo proteínas transmembranas, tais como os receptores do tipo Toll (TLRs) e receptores de lectina do tipo C (CLRs), proteínas citoplasmáticas, como o ácido retinóico gene induzível I (RIG-I)-like receptors (RLRs) e receptor do tipo NOD (NLRs) (TAKEUCHI; AKIRA, 2010). Neste trabalho, abordaremos com mais detalhes os PRRs da classe dos NLRs.

Cerca de 20 membros da família NLR estão descritos em humanos e, ao menos, 34 genes em camundongos. Estes receptores são expressos em muitos tipos celulares, como células do sistema imunológico e epiteliais (FRANCHI et al., 2009).

A estrutura dos NLRs é composta por três domínios: uma região C-terminal formada por um domínio com repetições ricas em leucina (LRR), podendo ser responsável pelo reconhecimento de PAMPs; um domínio central conhecido como domínio de ligação de nucleotídeos (NBD ou NACHT), responsável pela auto oligomerização; e a região efetora variável N-terminal, que divide os NLRs em subfamílias como os NLRBs contendo o domínio BIR (Baculovirus IAP repeat), os NLRCs contendo o domínio CARD (Caspase activation and recruitment domain) e NLRPs, que contém o domínio PYD (Pyrin domain) (Figura 6) (TING et al., 2008). 
Figura 6 - Esquema das proteínas da família dos receptores do tipo NOD

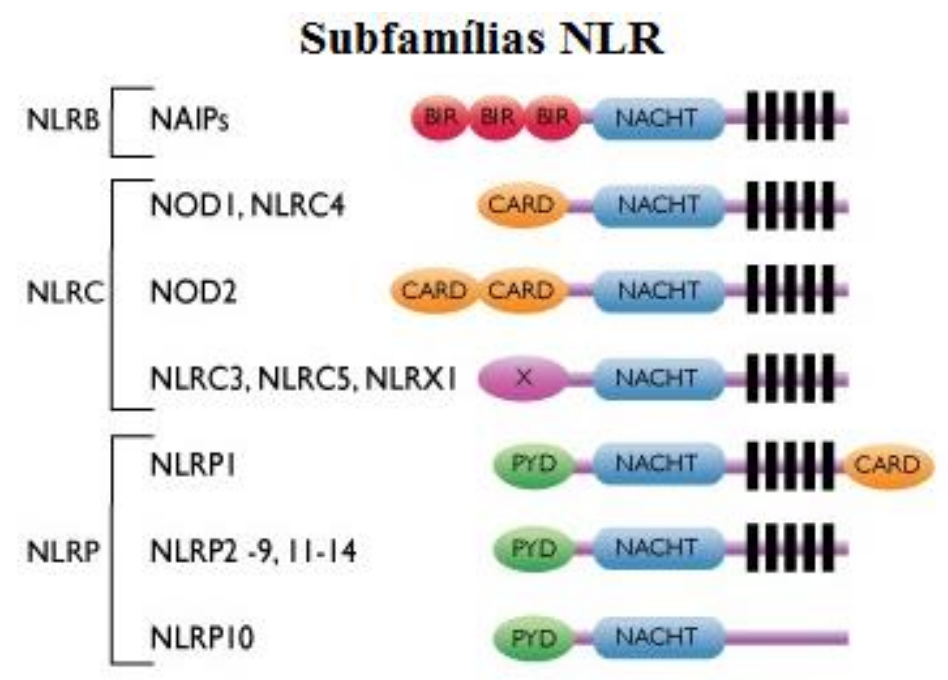

Representação dos membros da subfamília dos NLRs, demonstrando seus domínios: C-terminal com repetições ricas em leucina, domínio de ligação de nucleotídeos (NACHT) e domínio N-terminal variável responsável pela separação dos NLRs em subfamílias. Adaptado de http://www.invivogen.com/review-nlr

No ano de 1999 foi identificado o primeiro membro da família dos NLRs, chamado de NOD1 e também conhecido como NLRC1, descrito como um homólogo do regulador de apoptose APAF; em 2001 foi descrito NOD2 ou NLRC2, sendo estes dois receptores responsáveis por uma resposta pró-inflamatória dependente do fator de transcrição nuclear Kappa-B (NF-кB) semelhantes e independentes à resposta dos TLRs (INOHARA et al., 1999; INOHARA et al., 2001; OGURA et al., 2001).

Enquanto NOD1 é expresso ubiquamente, a expressão de NOD2 é restrita a monócitos, macrófagos, células dendríticas e células de Paneth do intestino (INOHARA et al. 2005). NOD1 e NOD2 reconhecem diferentes motivos estruturais derivados de peptidoglicana da parede celular de bactérias gram-positivas e gram-negativas. A atividade de NOD1 é desencadeada pela presença de $\gamma$-D-glutamyl-meso-diaminopimelic acid (meso-DAP) ou (iEDAP), um aminoácido presente na peptidioglicana de todas bactérias gram-negativas e algumas bactérias gram-positivas, incluindo os gêneros Listeria e Bacillus (CHAMAILLARD et al., 2003; GIRARDIN et al, 2003a). NOD2 reconhece muramil dipeptídeo (MDP) existente em todos os tipos de peptídeoglicanos (GIRARDIN et al, 2003b) e também há relatos sugerindo a interação deste receptor com RNA viral presente no citoplasma de células infectadas (DUGAN et al., 2009; LUPFER et al., 2013).

Outros NLRs podem formar complexos multiproteicos denominados inflamassomas, que por sua vez, levam ao recrutamento e ativação de pró-caspase-1, resultando na clivagem e liberação das citocinas pró-inflamatórias dependentes de caspase-1, IL-1 $\beta$ e IL-18, além de 
um tipo de morte celular inflamatória denominada piropitose (BORTOLUCI; MEDZHITOV, 2010; SUTTERWALA et al., 2006).

A ativação da caspase-1 envolve o processo autocatalítico da proenzima inativa prócaspase-1 de 45kDa, para gerar duas subunidades, p20 (20kDa) e p10 (10kDa) que formam a enzima ativa caspase-1, capaz de clivar pró-IL1 $\beta$ e pró-IL-18. Estas subunidades podem ser identificadas com anticorpos específicos (anti-p10 ou anti-p20) por meio de western blotting (CASSEL et al., 2008).

Dentre os NLRs, formadores de inflamassomas, podemos citar NLRP1, NLRP3, NLRP6, NLRP7, NLRP12, NAIP5 e NLRC4. Outro receptor citosólico formador de inflamassoma é o AIM2, esse receptor pertence à família das proteínas PYHIN e não à família dos NLRs, e tem sua ativação ligada ao DNA liberado no citosol celular, após a lise de alguns patógenos, por exemplo, Francisella tularensis (BURCKSTUMMER et al., 2009; FERNANDES-ALNEMRI et al., 2009; FERNANDES-ALNEMRI et al., 2010; HORNUNG et al., 2009; RATHINAM et al., 2010; ROBERTS et al., 2009). Cada receptor é ativado por diferentes agonistas, sendo que NLRP1 reconhece a toxina letal anthrax (LT) (NOUR et al., 2009), enquanto NLRP6 não tem seus sinais de ativação completamente elucidados e pode estar comprometido com o controle da microbiota intestinal (ELINAV et al., 2011). NLRP7 está envolvido no reconhecimento de lipopeptídeos acilados bacterianos (acLP) e NLRP12 reconhece o agente causador da peste bubônica, Yersinia pestis. O inflamassoma NAIP5/NLRC4 é ativado principalmente por flagelina citosólica, uma subunidade monomérica presente em quase todas as bactérias gram-negativas e gram-positivas que é levada ao citosol das células através de sistemas de secreção do tipo III (T3SS) em Salmonella typhimurium e tipo IV (T4SS) em Legionella pneumophila (HALFF et al., 2012; LIGHTFIELD et al., 2008; LIGHTFIELD et al., 2011).

$\mathrm{O}$ receptor mais estudado dentre os inflamassomas tem sido o Nalp3/NLRP3/CIAS1/Criopirina, e uma grande variedade de estímulos já foram descritos como seus ativadores, tais como LPS (KANNEGANTI et al., 2007; MARIATHASAN et al., 2006; SUTTERWALA et al., 2006), ATP e toxinas bacterianas formadoras de poros (MARIATHASAN et al., 2006), cristais de urato (MARTINON et al., 2006), DNA e RNA bacteriano (KANNEGANTI et al., 2006; MURUVE et al., 2008), muramil dipeptídeo bacteriano (MDP) (MARTINON et al., 2004; MARINA-GARCÍA et al., 2008), componentes da parede celular de fungos, zimozan e manana (LAMKANFI; MALIREDDI; KANNEGANTI, 2009), hemozoína de Plasmodium (DOSTERT et al., 2009; SHIO et al., 
2009), amianto (CASSEL et al., 2008; DOSTERT et al., 2008) e certos tipos de sílica $\left(\mathrm{SiO}_{2}\right)$ (CASSEL et al., 2008; DOSTERT et al., 2008; HORNUNG et al., 2008).

Para a ativação de Nalp3 in vitro são necessários dois sinais, um fornecido por um agonista de TLR, para a produção das citocinas inativas pró-IL-1 $\beta$ e pró-IL-18, e outro pelos diversos estímulos que podem provocar a perda da integridade das membranas lisossomal ou plasmática. Esta perda da integridade da membrana plasmática parece ser detectada por meio do efluxo de íons potássio, enquanto o rompimento do lisossomo é detectado pelo extravasamento do seu conteúdo, por exemplo, espécies reativas do oxigênio e catepsina $B$, para o citosol (BORTOLUCI; MEDZHITOV, 2010; EISENBARTH et al., 2008). Após ativação dos NLRs ocorre a oligomerização das moléculas, através do domínio NATCH, o que permite a aproximação das regiões $\mathrm{N}$-terminais e o recrutamento de moléculas adaptadoras, quando necessárias (MARTINON; MAYOR; TSCHOPP, 2009; SCHRODER; TSCHOPP, 2010).

O inflamassoma Nalp3 não consegue ativar a caspase-1 diretamente devido ao seu domínio N-terminal do tipo PYD (Figura 7); portanto, uma vez ativado, este receptor recruta a molécula adaptadora ASC (apoptosis-associated speck-like protein containing a CARD). ASC é formado por um domínio C-terminal recrutador e ativador de caspases (CARD) e um domínio N-terminal PYD. Por meio de interações homotípicas PYD-PYD, ASC se liga a Nalp3 e recruta a pró-caspase-1 via interações CARD-CARD. Diferentemente, inflamassomas NLRC4 contém o domínio N-terminal CARD capaz de interagir diretamente com a prócaspase-1 ou também recrutar ASC, podendo o complexo inflamassoma NLRC4 conter ou não ASC. Estas vias de ativação dos inflamassomas resultam no recrutamento e clivagem proteolítica da caspase-1 para a sua forma ativa, que por sua vez, medeia a ativação das citocinas IL-1 $\beta$ e IL-18, que foram geradas pela via do NF- $\kappa B$, induzidas por agonistas de TLRs e NODs ou citocinas inflamatórias, que estavam armazenadas nas suas formas inativas no citoplasma (MARTINON; TSCHOPP, 2006; MARIATHASAN, 2007; OGURA; SUTTERWALA; FLAVELL, 2006). 
Figura 7 - Representação esquemática de NLRP3, NLRC4, ASC e caspase-1
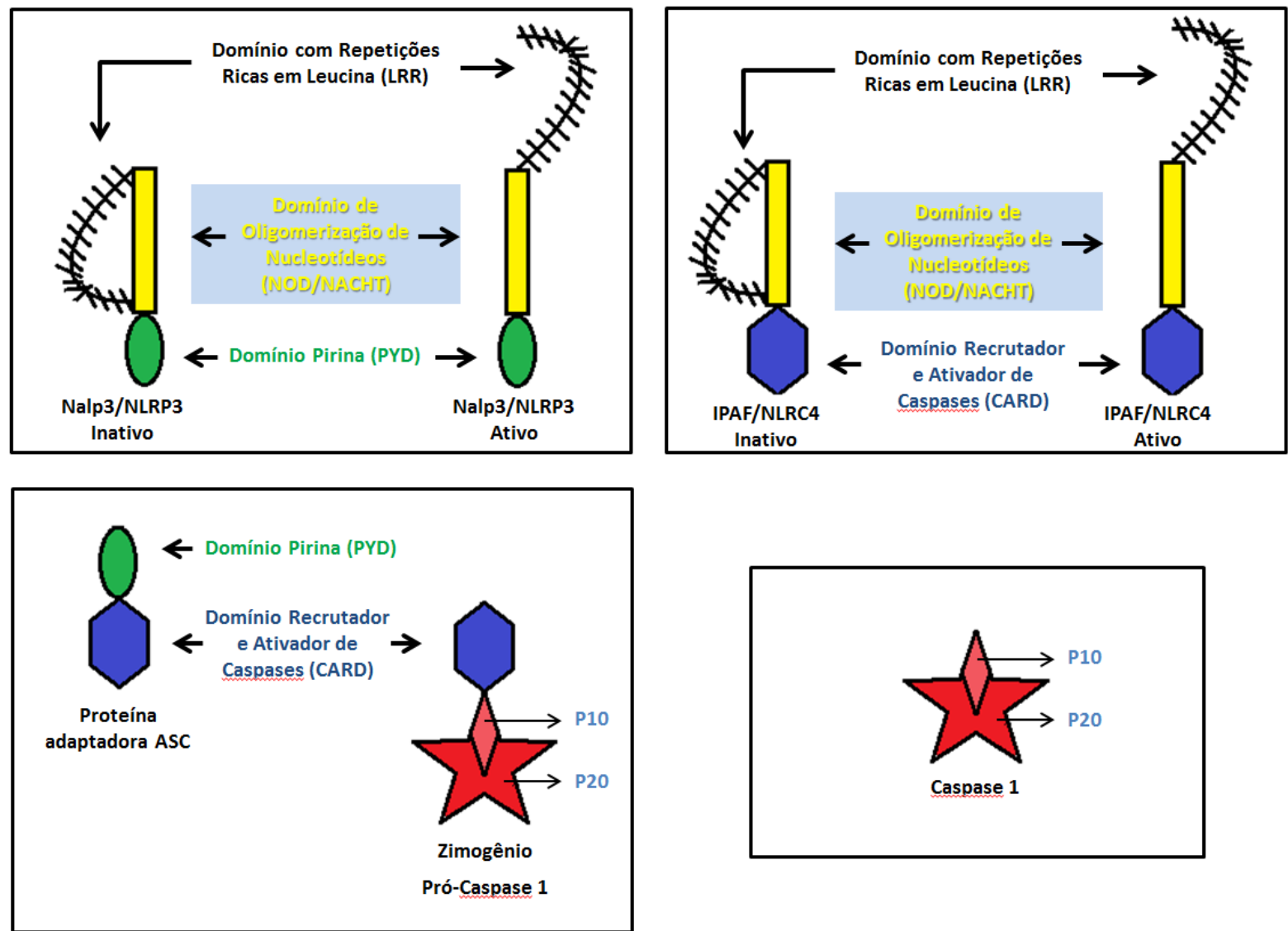

Modelo das proteínas NLRP3 e NLRC4 auto inibidas e ativas, demonstrando seus domínios: LRR, NOD/NACHT e PYD em Nlrp3 ou CARD em Nlrc4. ASC com seus domínios PYD e CARD. Pró-caspase-1 com domínio CARD e subunidades P10 e P20. Caspase-1 ativa formado pelas subunidades P10 e P20.

Trabalhos realizados por diferentes autores (EISENBARTH et al., 2008; HORNUNG et al., 2008; KOOL et al., 2008) sugerem a via do inflamassoma Nalp3 como responsável pela atividade imunoestimuladora dos adjuvantes de alumínio. Outros relatos afirmam que certas partículas de sílica $\left(\mathrm{SiO}_{2}\right)$ ativam o inflamassoma Nalp3 (CASSEL et al., 2008; DOSTERT et al., 2008; HORNUNG et al., 2008), logo, como a SBA-15 é composta por partículas de $\mathrm{SiO}_{2}$, é pressuposto que este promissor adjuvante também esteja potencializando a resposta imunológica por meio desta via. Desse modo, é de extrema importância avaliar o papel da sílica mesoporosa nanoestruturada SBA-15 na ativação do inflamassoma Nalp3, e a partir dos resultados obtidos direcionar novos estudos. 


\section{OBJETIVOS}

Avaliar o papel da sílica mesoporosa nanoestruturada SBA-15 na ativação do inflamassoma Nalp3 em macrófagos peritoneais e derivados da medula óssea.

Investigar os mecanismos de interação dos macrófagos com a SBA-15. 


\section{MATERIAIS E MÉTODOS}

\subsection{Animais}

Todos os procedimentos realizados foram aprovados pelas comissões de ética para utilização de animais do Instituto Butantan, protocolo ${ }^{\circ}$ 1219/14, e Instituto de Ciências Biomédicas da Universidade de São Paulo, registrado como n ${ }^{\circ}$ 34, fls. 17 do livro 03.

Camundongos C57BL/6 machos com 6-8 semanas de idade, cedidos pelo Biotério Central do Instituto Butantan, foram mantidos em condições convencionais no biotério de manutenção do Laboratório de Imunoquímica do Instituto Butantan, em caixas de polipropileno medindo 30x20x13cm forradas com maravalha, cinco animais por caixa, com água e ração ad libitum até a sua utilização.

\subsection{Sílica mesoporosa nanoestruturada - SBA-15}

A sílica mesoporosa nanoestruturada SBA-15 foi produzida e fornecida pelo laboratório Cristália (Lote: SM_01_00_0002). As amostras de SBA-15 foram sintetizadas utilizando um copolímero tribloco, o poli-[óxido de etileno]-poli-[óxido de propileno]-poli[óxido de etileno] Pluronic P123, EO20PO70EO20, PM= 5800 - BASF (BASF ChemicalCo.,Mount Olive, NJ, EUA), o tetraetil-ortosilicato [TEOS] adquirido da Fluka (Fluka/Sigma Chemical Co., Milwaukee, WI, EUA). O ácido hidroclorídrico foi adquirido da Fisher (Fisher Scientific Co.,Pittsburgh, PA, EUA). Toda a caracterização da síntese e os reagentes foram utilizados conforme descrito por Matos et al. (2001).

O material foi ressuspenso em PBS, na concentração de $5 \mathrm{mg} / \mathrm{mL}$, autoclavado e mantido a $4{ }^{\circ} \mathrm{C}$ até sua utilização.

\subsection{Obtenção dos macrófagos peritoneais (MP)}

Os animais foram inoculados com $1 \mathrm{~mL}$ de Tioglicolato 3\% - OXOID (UNIPATH LTD., Basingstoke, Hampshire, Inglaterra), pela via intraperitoneal e, após 4 dias, foram eutanasiados por inalação de $\mathrm{CO}_{2}$ em câmara anestésica adequada e por profissional qualificado, seguindo as normas vigentes do CONCEA. Após a eutanásia, os animais foram embebidos em álcool $70 \%$ e transportados até o fluxo laminar onde foi realizado o lavado 
peritoneal com a inoculação de $5 \mathrm{~mL}$ de meio DMEM - LGC Biotecnologia (Labtrade Ltda., São Paulo, SP, Brasil) gelado.

\subsection{Obtenção de M-CSF do sobrenadante da cultura de células L929}

As células L929 foram gentilmente cedidas pela Dra. Maria Regina D’Império Lima, do Departamento de Imunologia - ICB-USP. As células foram colocadas em garrafa de cultura de $25 \mathrm{~cm}^{2}$ (Corning Inc. - NY, EUA) em $5 \mathrm{~mL}$ de meio DMEM completo (10\% SFB [Cultilab, SP, Brasil], $100 \mu \mathrm{g} / \mathrm{mL}$ de penicilina-estreptomicina [Gibco, Invitrogen Corp., CA, EUA]) até confluírem. Após este período, as células foram expandidas para uma garrafa de 75 $\mathrm{cm}^{2}$ contendo $20 \mathrm{~mL}$ de meio DMEM completo, até entrarem em confluência novamente, então, mantidas por 5 dias para a produção de M-CSF. Após esta etapa, o sobrenadante da cultura foi coletado, centrifugado e mantido a $-20^{\circ} \mathrm{C}$ até a sua utilização.

\subsection{Obtenção dos macrófagos derivados da medula óssea (MDMO)}

Estes procedimentos foram realizados, sempre que possível, com os mesmos animais utilizados para a obtenção dos MP.

Os fêmures dos camundongos foram removidos. Em uma placa de petri os ossos foram cortados com auxilio de uma tesoura e, usando uma seringa com agulha de 0,45 milímetros, o interior do osso foi lavado com meio DMEM para a retirada das células da medula óssea. $\mathrm{O}$ material foi homogeneizado e transferido para uma garrafa de cultura de $75 \mathrm{~cm}^{2}$ (1 fêmur) ou $150 \mathrm{~cm}^{2}$ (2 fêmures) contendo meio DMEM completo suplementado com $30 \%$ do sobrenadante de células L929 e mantidos a $37{ }^{\circ} \mathrm{C}$, em atmosfera umidificada contendo $5 \%$ de $\mathrm{CO}_{2}$, durante 7 dias. Após 3 dias, foi adicionado mais $10 \mathrm{~mL}$ (por fêmur) de meio de cultura suplementado com $30 \%$ do sobrenadante de L929.

\subsection{Tratamento das células peritoneais}

As células obtidas do lavado peritoneal foram centrifugadas a $405 \times g$ durante 10 minutos à $10{ }^{\circ} \mathrm{C}$, o sobrenadante foi descartado, as células foram ressuspensas em $1 \mathrm{~mL}$ de meio de cultura, contadas, adicionadas em placas de 96 poços $\left(4\right.$ x $10^{5}$ células em $200 \mu \mathrm{L}$ de meio/poço) e incubadas a $37{ }^{\circ} \mathrm{C}$ e $5 \% \mathrm{CO}_{2}$ por 2 horas. Após este período, as células não aderentes foram retiradas por lavagem com meio de cultura e as células aderentes foram 
estimuladas com meio DMEM, Nano-SiO 2 (InvivoGen., San Diego, USA) (100 $\mu \mathrm{g} / \mathrm{mL})$ e SBA-15 (10-500 $\mu \mathrm{g} / \mathrm{mL})$ em triplicata. Após 18-24 horas, os sobrenadantes das culturas foram retirados e armazenados a $-80^{\circ} \mathrm{C}$ até a utilização.

\subsection{Tratamento dos macrófagos derivados da medula óssea}

Após a diferenciação, as culturas de macrófagos foram tripsinizadas, centrifugadas a $405 \times g$ durante 10 minutos a $10^{\circ} \mathrm{C}$, os sobrenadantes descartados, e as células ressuspensas em $1 \mathrm{~mL}$ de meio de cultura, contadas, adicionadas em placas de 96 poços $\left(2 \times 10^{5}\right.$ células em $200 \mu \mathrm{L}$ de meio/poço) e incubadas a $37{ }^{\circ} \mathrm{C}$ e $5 \% \mathrm{CO}_{2}$, durante 24 horas. Após este período, as células foram estimuladas com meio DMEM, Nano-SiO 2 (100-200 $\mu \mathrm{g} / \mathrm{mL})$, Hidróxido de Alumínio (Alum) $(200 \mu \mathrm{g} / \mathrm{mL})$ cedido pelo Instituto Butantan (Lote: IB-13/12) e SBA-15 (100-200 $\mu \mathrm{g} / \mathrm{mL})$, em triplicata na presença ou não de LPS de Escherichia coli 0111:B4 (Sigma Aldrich, St. Louis, MO, EUA) e Z-VAD-FMK (carbobenzoxy-valyl-alanyl-aspartyl[O-methyl] fluoromethylketone) (InvivoGen., San Diego, USA) $(20 \mu \mathrm{M}) .24$ horas após, os sobrenadantes das culturas foram retirados e armazenados a $-80^{\circ} \mathrm{C}$ até a utilização.

\subsection{Viabilidade celular}

A ação da SBA-15 sobre a viabilidade de macrófagos peritoneais foi avaliada pelo método de MTT (3-(4, 5-dimethylthiazol-2-yl)-2,5-di-phenyltetrazolium bromide) (MOSMANN, 1983). Ao término dos estímulos, os sobrenadantes dos poços foram aspirados, adicionados $60 \mu \mathrm{L}$ /poço da solução de MTT $(0,83 \mu \mathrm{g} / \mu \mathrm{L})$, em meio DMEM sem SFB, e as placas incubadas durante $4 \mathrm{~h}$ a $37{ }^{\circ} \mathrm{C}$ e $5 \% \mathrm{CO}_{2}$. Na sequencia, os sobrenadantes foram aspirados e adicionados $100 \mu \mathrm{L} /$ poço de DMSO (Dimetilsulfóxido - Merck -Darmstad, Alemanha). As placas permaneceram em repouso, à temperatura ambiente, por cinco minutos até a leitura em leitor de placas (Multiskan-EX, Labsystems, Helsinki, Finlândia), nos comprimentos de onda de $\lambda 540$ e $\lambda 620 \mathrm{~nm}$. A viabilidade celular foi calculada pela seguinte fórmula:

[(D.O. amostra $(540-620 \mathrm{~nm}) \times 100]$

[(média da D.O. controle $\left.\left.{ }_{(540-620 \mathrm{~nm})}\right)\right]$ 


\subsection{Inibição da fagocitose}

Para a inibição da fagocitose os macrófagos peritoneais foram pré-tratados com Citocalasina D (Sigma Aldrich, St. Louis, MO, EUA) $(10 \mu \mathrm{M})$ durante 30 minutos. Após esse período, o sobrenadante dos poços foi aspirado e as células estimuladas com meio DMEM, SBA-15 $(100 \mu \mathrm{g} / \mathrm{mL})$ e ATP (Sigma Aldrich, St. Louis, MO, EUA) (5 mM).

\subsection{Inibição da produção das espécies reativas do oxigênio (EROs)}

Para inibir a produção das espécies reativas do oxigênio (EROs), os macrófagos peritoneais foram pré-tratados com cloreto de difenileno-iodônio (DPI) (Sigma Aldrich, St. Louis, MO, EUA) $(10 \mu \mathrm{M})$ durante 30 minutos. Após esse período, o sobrenadante dos poços foi aspirado e as células estimuladas com meio DMEM e SBA-15 $(100 \mu \mathrm{g} / \mathrm{mL})$.

\subsection{Detecção de citocinas nos sobrenadantes das culturas}

A produção das citocinas IL-1 $\beta$ e IL-6 nos sobrenadantes das culturas foi analisada por ELISA. As dosagens foram realizadas em duplicata, utilizando sets BD OptEIA ${ }^{\mathrm{TM}}$ (Becton Dickinson, CA, EUA), seguindo as instruções do fabricante.

\subsection{Análises estatísticas}

A análise estatística foi realizada com o auxílio do programa GraphPadPrism, versão 5.1 para Windows, da GraphPadSoftware. O teste utilizado foi o One Way ANOVA, seguido pelo teste de Tukey. As diferenças entre os grupos foram consideradas significantes quando o valor $p<0.05$. 


\section{RESULTADOS}

\subsection{SBA-15 não é tóxica para macrófagos peritoneais}

A figura 8 mostra que a SBA-15 não é tóxica para macrófagos peritoneais, induzindo somente uma redução de $7 \%$ e $10 \%$ da viabilidade celular nas concentrações de 100 e 200 $\mu \mathrm{g} / \mathrm{mL}$, respectivamente. Nestas mesmas concentrações, não houve morte celular significativa quando comparada com a sílica comercial (Nano-SiO2) ou com o hidróxido de alumínio (Alum).

Figura 8 - Viabilidade de macrófagos peritoneais tratados com SBA-15, Nano-SiO2 e Hidróxido de Alumínio

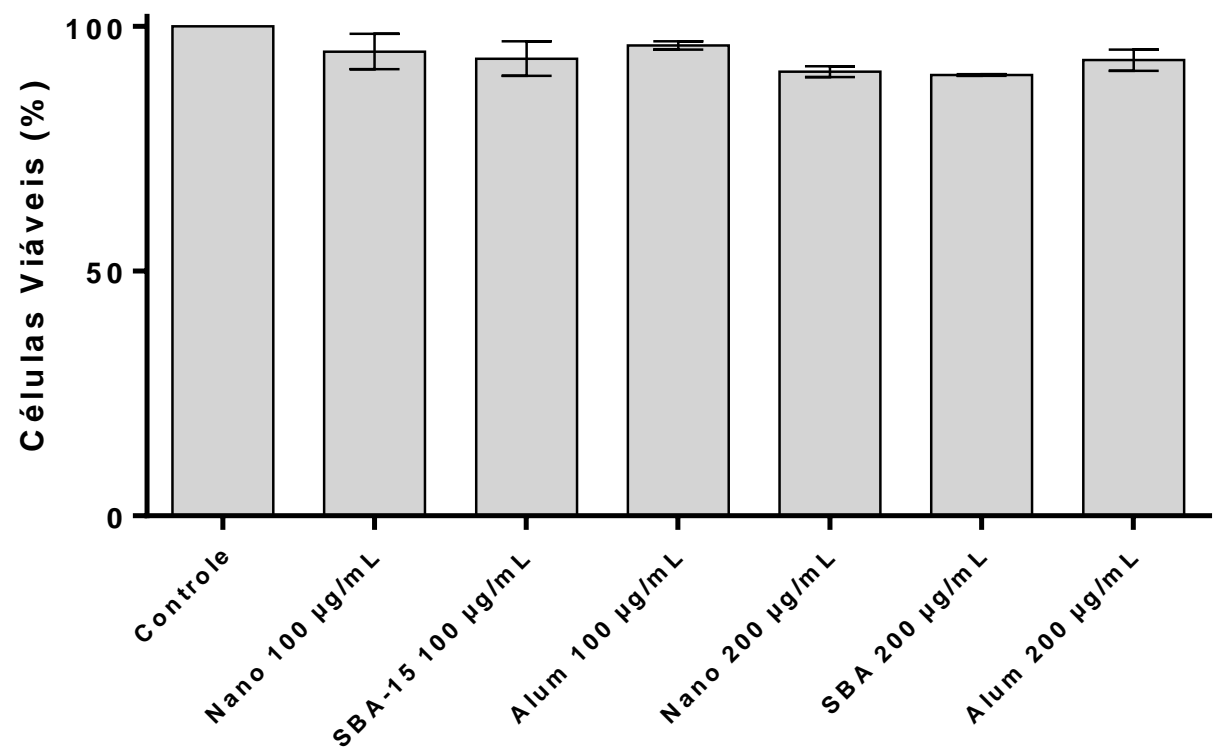

Macrófagos peritoneais provenientes de camundongos C57BL/6, previamente inoculados com Tioglicolato 3\%, foram cultivadas em placas de 96 poços $\left(4 \times 10^{5}\right.$ células/poço) e incubados por 2 horas. As células não aderentes foram retiradas por lavagem, e as células remanescentes foram estimuladas com meio DMEM, SBA-15 (100 e $200 \mu \mathrm{g} / \mathrm{mL})$, Nano-SiO2 (100 e $200 \mu \mathrm{g} / \mathrm{mL})$ e Alum $(100$ e $200 \mu \mathrm{g} / \mathrm{mL})$. A viabilidade celular foi avaliada após $24 \mathrm{~h}$ dos tratamentos, pelo método de MTT, e expressa em porcentagem. Os experimentos foram repetidos ao menos três vezes, com o mesmo perfil de resultados e os dados apresentados são provenientes de um experimento representativo.

\subsection{SBA-15 induz a secreção de IL-1ß em macrófagos peritoneais (MP)}

Sabe-se que a ativação dos diferentes inflamassomas, incluindo Nalp3, estão envolvidos na ativação da protease caspase-1, culminando na clivagem das citocinas pró-

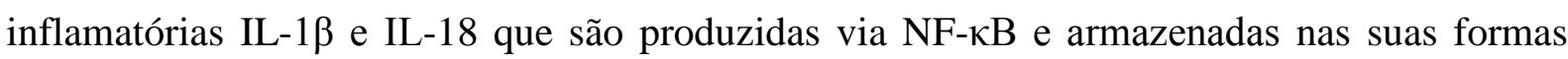


inativas no citosol. Portanto, uma das formas para avaliar a ativação do inflamassoma é pela detecção dessas citocinas no sobrenadante das culturas como um indicativo da ativação de caspase-1. Como parâmetro dessa ativação foi avaliada a produção de IL-1 $\beta$ por MP, frente a estímulos da SBA-15 $(100 \mu \mathrm{g} / \mathrm{mL})$, comparando com um agonista de Nalp3 (Nano-SiO ${ }_{2}-$ InvivoGen) $(100 \mu \mathrm{g} / \mathrm{mL})$ e, como controle negativo, as células foram mantidas apenas com meio de cultura (Sem tratamento).

Após 18-24 horas de cultura com os estímulos, o sobrenadante dos MP foi coletado para a detecção de IL-1 $\beta$ por ELISA. Como observado na Figura 9, a SBA-15 foi capaz de induzir a produção de IL-1 $\beta$ a níveis semelhantes aos induzidos pelo $\mathrm{Nano}-\mathrm{SiO}_{2}$, sugerindo a ativação do inflamassoma e consequentemente da caspase-1, essencial para a secreção desta citocina. Também foi observado que a ativação frente ao estímulo de SBA-15 ocorre de uma forma dependente da concentração, sendo possível detectar níveis mais elevados de IL-1 $\beta$ nos sobrenadantes das culturas, quando adicionado doses crescentes da sílica (10-500 $\mu \mathrm{g} / \mathrm{mL})$ (Figura 10).

Figura 9 - Análise da produção de IL-1 $\beta$ por macrófagos peritoneais estimulados com Nano$\mathrm{SiO}_{2}$ ou SBA-15

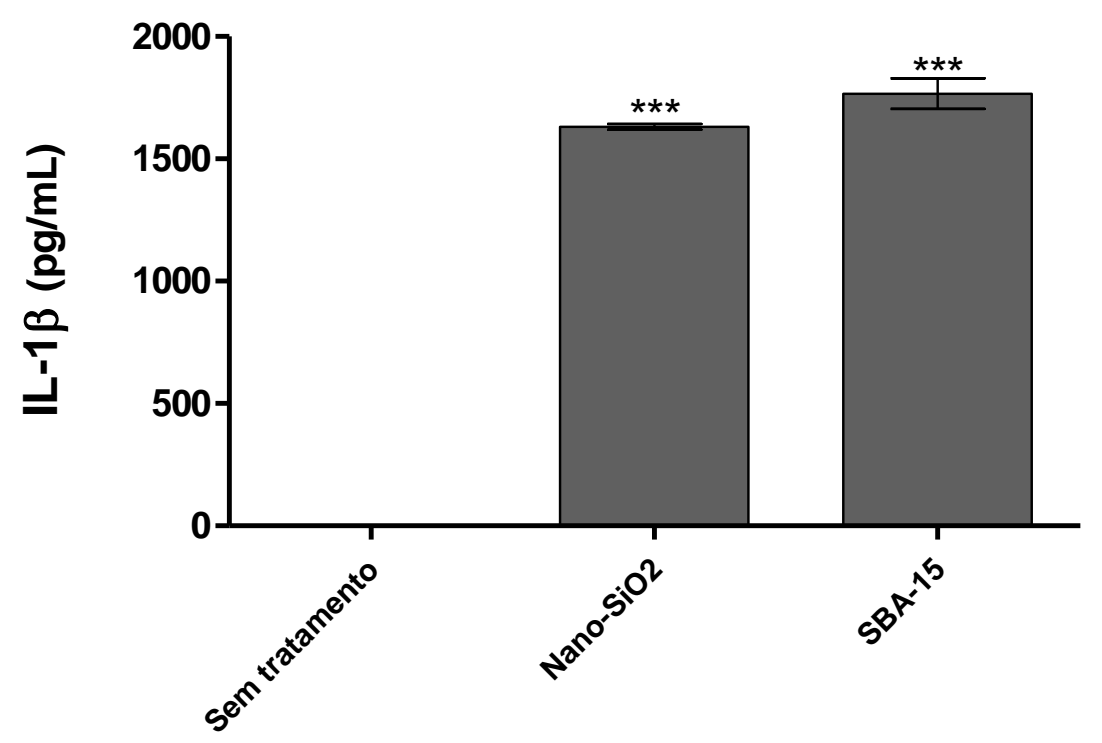

Macrófagos peritoneais provenientes de camundongos C57BL/6, previamente inoculados com Tioglicolato 3\%, foram cultivados em placas de 96 poços $\left(4 \times 10^{5}\right.$ células/poço) e incubados por 2 horas. As células não aderentes foram retiradas por lavagem, e as células remanescentes foram estimuladas com meio DMEM, Nano-SiO2 (100 $\mu \mathrm{g} / \mathrm{mL})$ e SBA-15 (100 $\mu \mathrm{g} / \mathrm{mL})$. Após 24 horas, os sobrenadantes das culturas foram retirados para análise da produção de IL-1 $\beta$ por ELISA. Os experimentos foram repetidos ao menos três vezes, com o mesmo perfil de resultados e os dados apresentados são provenientes de um experimento representativo. ***p<0.001 em relação ao grupo controle (Sem tratamento). 
Figura 10 - Análise da produção de IL-1 $\beta$ por macrófagos peritoneais estimulados com SBA15

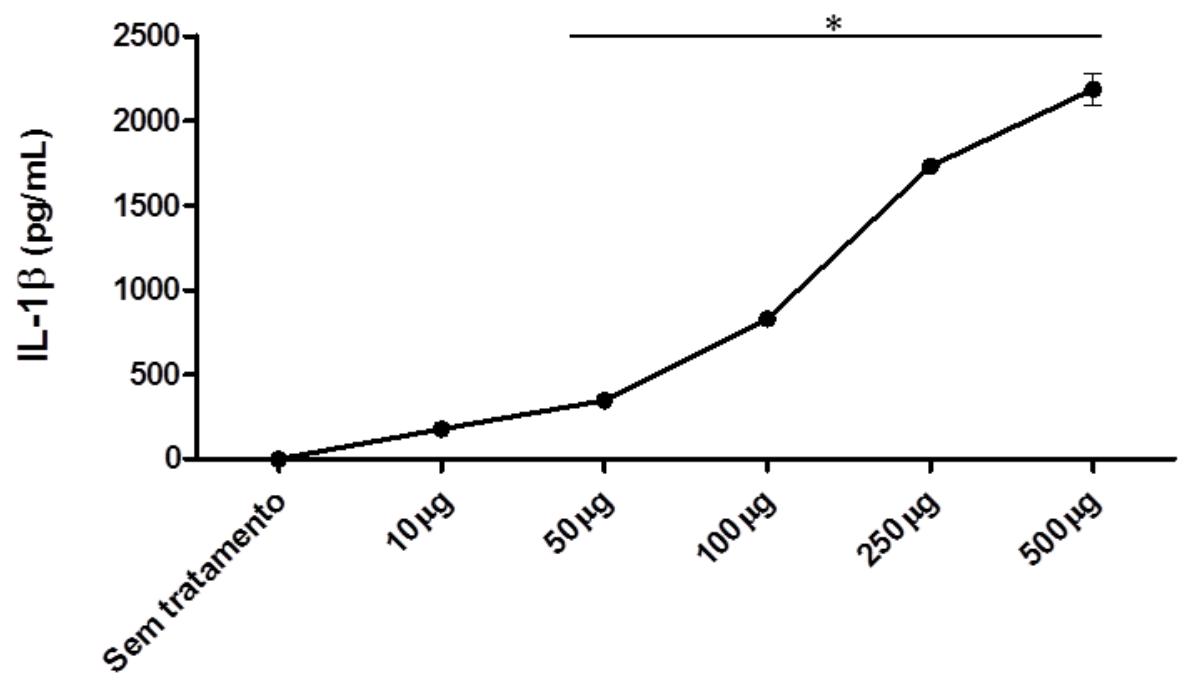

Macrófagos peritoneais provenientes de camundongos C57BL/6, previamente inoculados com Tioglicolato 3\%, foram cultivados em placas de 96 poços ( 4 × $10^{5}$ células/poço) e incubados por 2 horas. As células não aderentes foram retiradas por lavagem, e as células remanescentes foram estimuladas com meio DMEM e SBA-15 (10-500 $\mu \mathrm{g} / \mathrm{mL}$ ). Após 18 horas, os sobrenadantes das culturas foram retirados para análise da produção de IL-1 $\beta$ por ELISA. Os experimentos foram repetidos ao menos três vezes, com o mesmo perfil de resultados e os dados apresentados são provenientes de um experimento representativo. *p<0.001 em relação ao grupo controle (Sem tratamento).

\subsection{SBA-15 induz a secreção de IL-1ß, dependente de caspase-1, em macrófagos derivados da medula óssea (MDMO)}

Para a ativação do inflamassoma in vitro são necessários dois sinais, um proveniente de receptores tipo Toll, para a produção das citocinas inativas pró-IL-1 $\beta$ e pró-IL-18 e, um agonista para induzir a oligomerização dos NLRs formadores de inflamassoma. Para o primeiro sinal, as células receberam $1 \mu \mathrm{g} / \mathrm{mL}$ de LPS durante 4 horas. Como segundo sinal, as células foram colocadas frente a estímulos de SBA-15 $(200 \mu \mathrm{g} / \mathrm{mL})$ comparando com Nano$\mathrm{SiO}_{2}(200 \mu \mathrm{g} / \mathrm{mL})$ e Alum $(200 \mu \mathrm{g} / \mathrm{mL})$. Os controles negativos utilizados foram apenas os estímulos sem a presença do primeiro sinal, só o primeiro sinal ou meio de cultura.

Após 24 horas de cultura com os estímulos, os sobrenadantes dos MDMO foram coletados para a detecção de IL-1 $\beta$ por ELISA. A Figura 11, mostra que na presença apenas do primeiro sinal já houve uma produção basal de IL-1 $\beta$, sendo essa produção significativamente aumentada quando recebido os dois sinais. Ainda, foi observado que a SBA-15 e Nano-SiO $\mathrm{S}_{2}$ foram, consideravelmente, melhores agonistas quando comparados com o Hidróxido de Alumínio. Também foi confirmado que a presença dos dois sinais é imprescindível para a ativação do inflamassoma NLRP3, considerando que as células que receberam apenas o segundo sinal não produziram IL-1 $\beta$. 
Como já mencionado, a ativação do inflamassoma culmina na maturação da serinoprotease caspase-1, sendo a secreção de IL-1 $\beta$ dependente de caspase-1. Para avaliarmos o envolvimento da caspase-1 nos resultados obtidos com a SBA-15, os macrófagos foram estimulados com SBA-15 (100 $\mu \mathrm{g} / \mathrm{mL})$, na presença ou não do inibidor de caspase-1 Z-VADFMK $(20 \mu \mathrm{M})$, para a análise da secreção de IL-1 $\beta$ nos sobrenadantes das culturas. Como esperado, na presença de Z-VAD-FMK, os níveis de IL-1 $\beta$ foram semelhantes à produção basal, onde as células foram apenas primadas com LPS (Figura 12).

Figura 11 - Análise da produção de IL-1 $\beta$ por macrófagos derivados da medula óssea estimulados com SBA-15, Nano-SiO ${ }_{2}$ ou Hidróxido de Alumínio

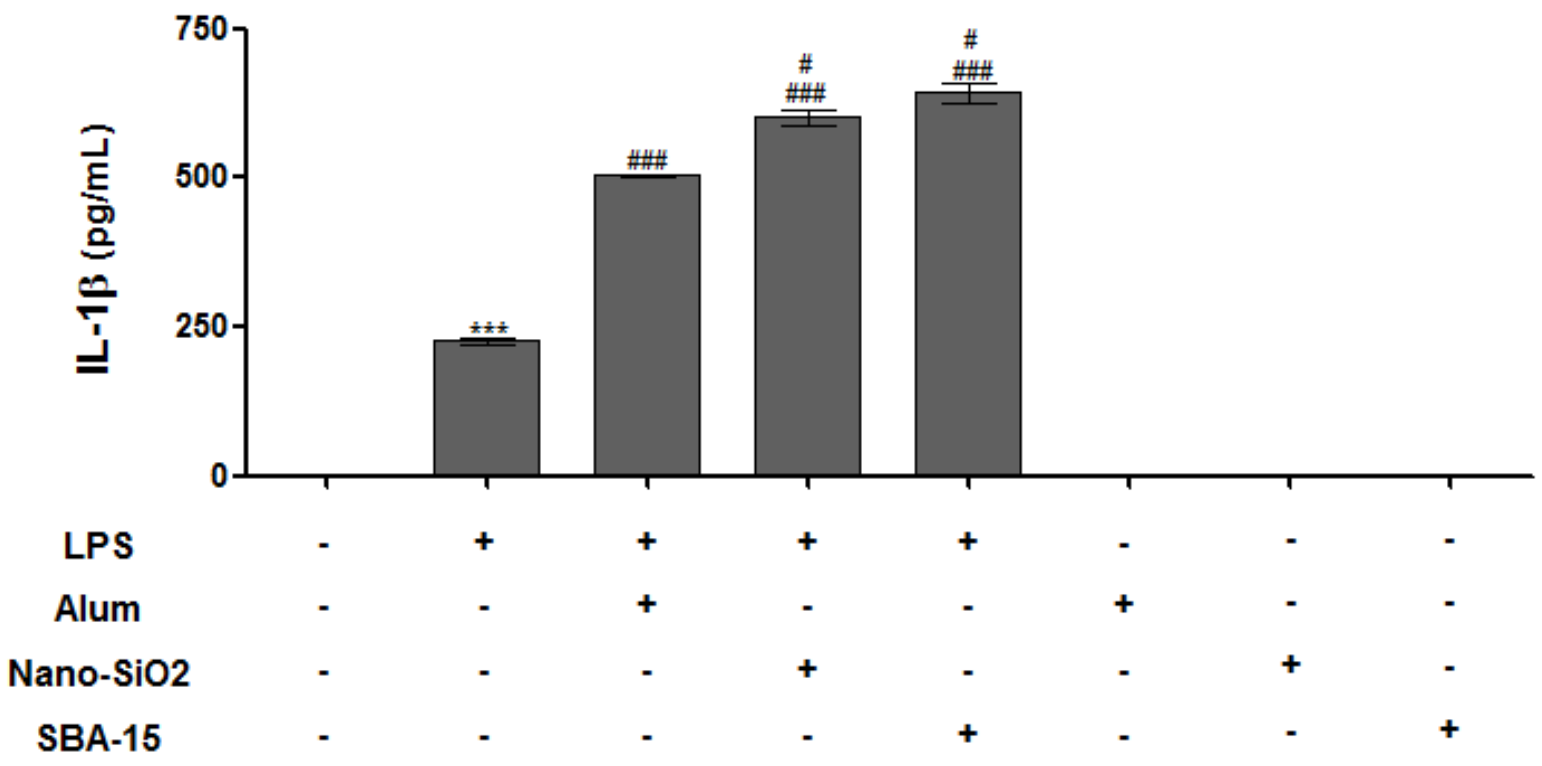

MDMO provenientes de camundongos C57BL/6 foram cultivados em placas de 96 poços (2x $10^{5}$ células/poço) e estimulados com meio DMEM, Nano-SiO2 (200 $\mu \mathrm{g} / \mathrm{mL})$, SBA-15 $(200 \mu \mathrm{g} / \mathrm{mL})$ e Alum $(200 \mu \mathrm{g} / \mathrm{mL}) \mathrm{na}$ presença ou não de LPS (1 $\mu \mathrm{g} / \mathrm{mL}-4 \mathrm{~h})$. Após 24 horas, os sobrenadantes das culturas foram retirados para análise da produção de IL-1 $\beta$ por ELISA. Os experimentos foram repetidos ao menos três vezes, com o mesmo perfil de resultados e os dados apresentados são provenientes de um experimento representativo. ***p<0.001 em relação ao grupo controle. \#\#\#p<0.001 em relação ao grupo LPS. \#p<0,05 em relação ao grupo LPS+Hidróxido de Alumínio. 
Figura 12 - Análise da produção de IL-1 $\beta$ por macrófagos derivados da medula óssea estimulados com SBA-15e Z-VAD-FMK

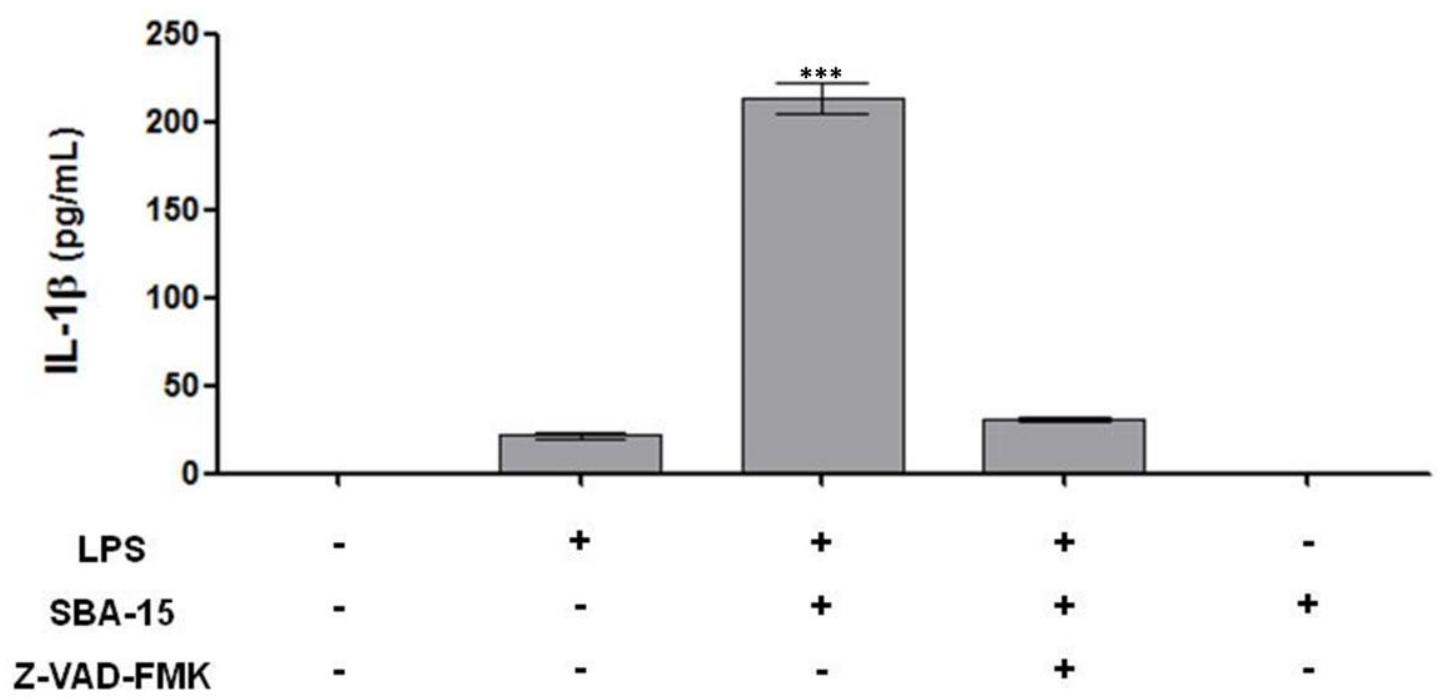

MDMO provenientes de camundongos C57BL/6 foram cultivados em placas de 96 poços ( $2 \times 10^{5}$ células/poço) e estimulados com meio DMEM e SBA-15 $(100 \mu \mathrm{g} / \mathrm{mL})$ na presença ou não de LPS $(1 \mu \mathrm{g} / \mathrm{mL}-4 \mathrm{~h})$ e Z-VADFMK $(20 \mu \mathrm{M})$. Após 24 horas, os sobrenadantes das culturas foram retirados para análise da produção de IL-1 $\beta$ por ELISA. Os experimentos foram repetidos ao menos três vezes, com o mesmo perfil de resultados e os dados apresentados são provenientes de um experimento representativo. ${ }^{* * *} \mathrm{p}<0.001 \mathrm{em}$ relação ao grupo controle.

\subsection{SBA-15 não induz a secreção de IL-6 em macrófagos derivados da medula óssea (MDMO)}

Citocinas pró-inflamatórias, como TNF- $\alpha$ e IL-6, são independentes da ativação de inflamassoma, enquanto IL-1 $\beta$ e IL-18 necessitam da ativação do inflamassoma e caspase-1. Para comprovar o envolvimento da SBA-15 na ativação de caspase-1 e não de outra via, foi analisado a produção das citocinas IL-6 e IL-1 $\beta$ nos sobrenadantes das culturas estimuladas com $10 \mathrm{ng} / \mathrm{mL}$ de LPS (grupo: LPS), $100 \mu \mathrm{g} / \mathrm{mL}$ de SBA-15 (grupo: SBA-15), na presença ou não de $1 \mu \mathrm{g} / \mathrm{mL}$ de LPS, durante 4 horas (grupos: LPS primado; LPS primado+LPS; LPS primado+SBA-15) e $20 \mu \mathrm{M}$ de Z-VAD-FMK (grupo: LPS primado+SBA-15+Z-VAD-FMK).

O estímulo com a SBA-15 não induziu a produção de IL-6 (Figura 13A). Quando as células foram primadas com $1 \mu \mathrm{g} / \mathrm{mL}$ de LPS durante 4 horas, houve alta produção dessa citocina (grupo:LPS primado) e a presença da SBA-15 não interferiu nessa produção (grupo: LPS primado+SBA-15), confirmando que este adjuvante não está envolvido na via de transcrição da IL-6. Comprovando a ativação do inflamassoma e caspase-1, a SBA-15 induziu a produção de IL-1 $\beta$ (grupo: LPS primado+SBA-15), o que não aconteceu quando foi adicionado o inibidor de caspase-1 (grupo: LPS primado+SBA-15+Z-VAD-FMK) (Figura 13B). O estímulo de $10 \mathrm{ng} / \mathrm{mL}$ de LPS não elevou consideravelmente a produção de IL-1 $\beta$ 
(grupo: LPS) e o inibidor de caspase-1 não interferiu na produção de IL-6, confirmando a sua especificidade.

\subsection{O papel da fagocitose na secreção de IL-1ß induzida por SBA-15}

Para entender como a SBA-15 estimula a via do inflamassoma para a secreção de IL$1 \beta$, foi testado se a atividade endocítica dos macrófagos era necessária para a produção de IL$1 \beta$, induzida pela SBA-15. Para inibir a fagocitose, as células foram pré-tratadas com citocalasina D, um inibidor da polimerização dos microfilamentos de actina e, então, estimuladas com SBA-15 e ATP. O uso da citocalasina D diminuiu, consideravelmente, a produção de IL-1 $\beta$ sobre o estimulo da SBA-15 (Figura 14), mas não afetou a produção de IL$1 \beta$, em resposta a estímulos de $\mathrm{ATP}$, que utiliza o receptor $\mathrm{P} 2 \mathrm{X} 7$, e não necessita da sua internalização para ativar o inflamassoma NLRP3, confirmando que os macrófagos estavam viáveis e capazes de secretar IL-1 $\beta$ dependente do inflamassoma NLRP3.

\subsection{A produção das espécies reativas do oxigênio (EROs) está envolvida na secreção de IL-1ß induzida por SBA-15}

Com o intuito de esclarecer o mecanismo celular pelo qual a SBA-15 desencadeia a ativação do inflamassoma, foi avaliada a exigência da geração de espécies reativas do oxigênio para a produção de IL-1 $\beta$ induzida pela SBA-15, uma vez que EROs têm sido implicados na ativação do inflamassoma, em resposta a muitos agonistas conhecidos de NLRP3. Para inibir a produção das EROs, as células foram pré-tratadas com cloreto de difenileno-iodônio (DPI), um inibidor químico da NADPH oxidase e, portanto, da produção de EROs, e, estimuladas com SBA-15. Como pode ser observado na figura 15, na presença de DPI a secreção de IL-1 $\beta$, nos sobrenadantes das culturas, foi significativamente diminuída. 
Figura 13 - Análise da produção das citocinas IL-6 e IL-1 $\beta$ por macrófagos derivados da medula óssea estimulados com LPS, SBA-15 e Z-VAD-FMK

A

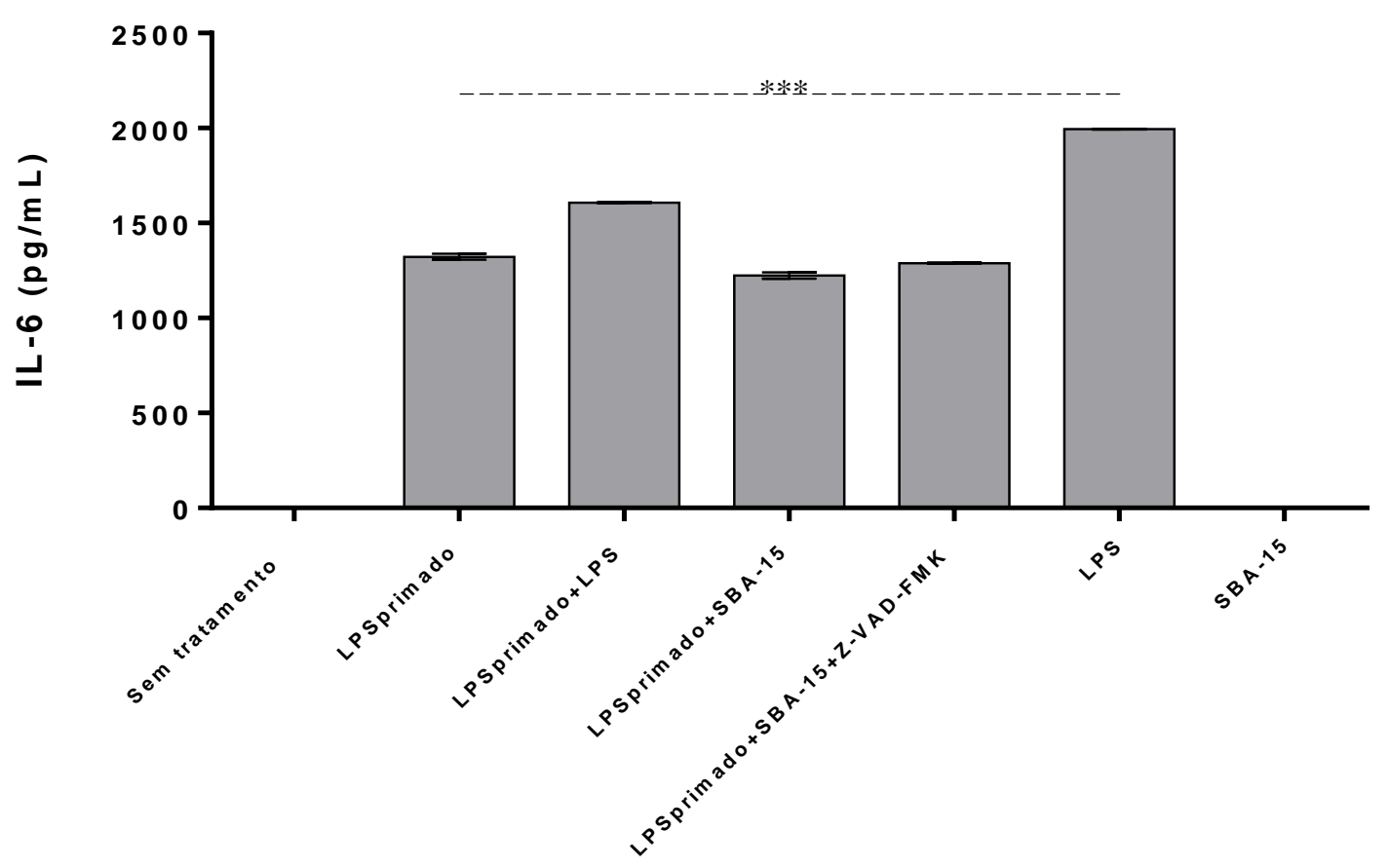

B

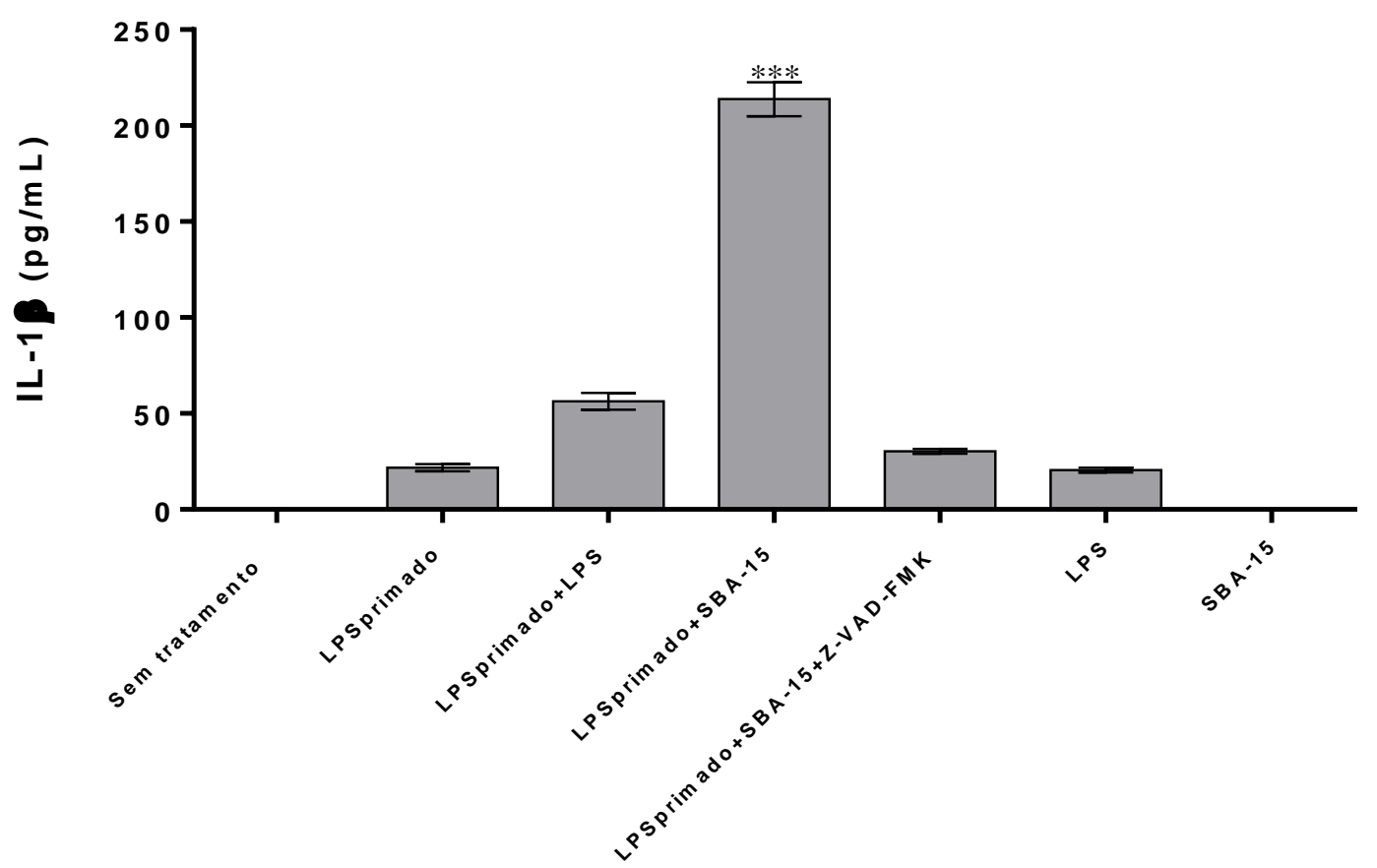

MDMO provenientes de camundongos C57BL/6 foram cultivados em placas de 96 poços $\left(2 \times 10^{5}\right.$ células/poço) e estimulados com meio DMEM, LPS (10 ng/mL) e SBA-15 (100 $\mu \mathrm{g} / \mathrm{mL})$ na presença ou não de LPS $(1 \mu \mathrm{g} / \mathrm{mL}-4 \mathrm{~h})$ e Z-VAD-FMK $(20 \mu \mathrm{M})$. Após 24 horas, os sobrenadantes das culturas foram retirados para análise da produção de IL-6 (A) e IL-1 $\beta$ (B) por ELISA. Os experimentos foram repetidos ao menos três vezes, com o mesmo perfil de resultados e os dados apresentados são provenientes de um experimento representativo. ${ }^{* * *} \mathrm{p}<0.001 \mathrm{em}$ relação ao grupo sem tratamento. 
Figura 14 - Análise da produção de IL-1 $\beta$ por macrófagos peritoneais estimulados com SBA15 , ATP e citocalasina D

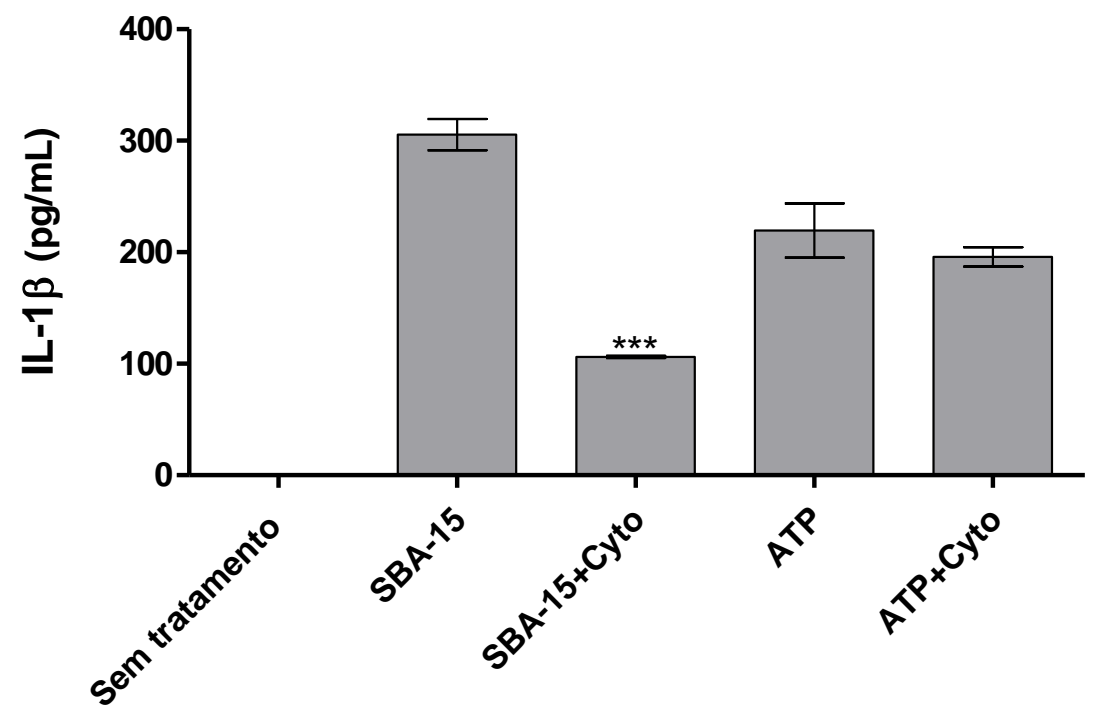

Macrófagos peritoneais provenientes de camundongos C57BL/6 previamente inoculados com Tioglicolato 3\%, foram cultivados em placas de 96 poços ( 4 × $10^{5}$ células/poço) e incubados por 2 horas. As células não aderentes foram retiradas por lavagem, e as células remanescentes foram estimuladas com meio DMEM, SBA-15 (100 $\mu \mathrm{g} / \mathrm{mL})$ e ATP $(5 \mathrm{mM})$ na presença ou não de citocalasina $\mathrm{D}(10 \mu \mathrm{M})$. Após 18 horas, os sobrenadantes das culturas foram retirados para análise da produção de IL-1 $\beta$ por ELISA. Os experimentos foram repetidos ao menos três vezes, com o mesmo perfil de resultados e os dados apresentados são provenientes de um experimento representativo. $* * * \mathrm{p}<0.001$ em relação ao grupo SBA-15.

Figura 15 - Análise da produção de IL-1 $\beta$ por macrófagos peritoneais estimulados com SBA15 e cloreto de difenileno-iodônio (DPI)

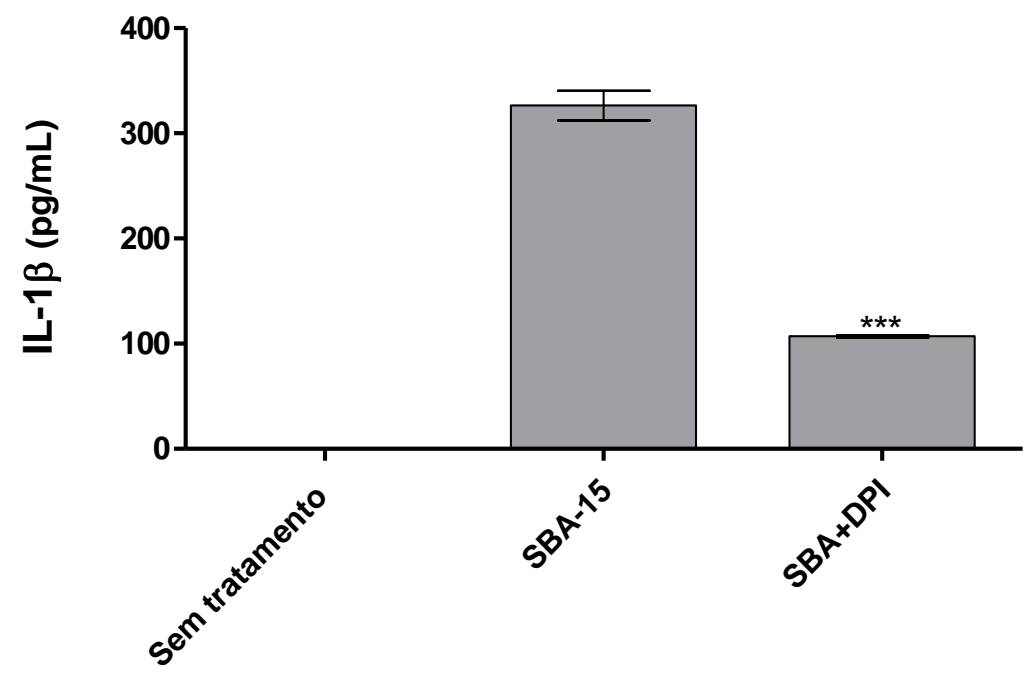

Macrófagos peritoneais provenientes de camundongos C57BL/6 previamente inoculados com Tioglicolato 3\%, foram cultivados em placas de 96 poços ( 4 × $10^{5}$ células/poço) e incubados por 2 horas. As células não aderentes foram retiradas por lavagem, e as células remanescentes foram estimuladas com meio DMEM, SBA-15 (100 $\mu \mathrm{g} / \mathrm{mL}$ ) na presença ou não de cloreto de difenileno-iodônio (DPI) $(10 \mu \mathrm{M})$. Após 18 horas, os sobrenadantes das culturas foram retirados para análise da produção de IL-1 $\beta$ por ELISA. Os experimentos foram repetidos ao menos três vezes, com o mesmo perfil de resultados e os dados apresentados são provenientes de um experimento representativo. $* * * \mathrm{p}<0.001$ em relação ao grupo SBA-15. 


\section{DISCUSSÃO}

A SBA-15, formada por $\mathrm{SiO}_{2}$ com estrutura altamente ordenada, poros interligados de aproximadamente $10 \mathrm{~nm}$ (ZHAO et al., 1998a, 1998b), tem sido estudada há mais de dez anos quanto a sua aplicabilidade como adjuvante para vacinas. Os resultados obtidos nesses estudos indicam que essa sílica é promissora para este tipo de aplicação, elevando os níveis de anticorpos, contra antígenos de natureza distinta, em camundongos de diferentes linhagens, imunizados utilizando SBA-15 na sua formulação. Comparando com o hidróxido de alumínio (Alum), um adjuvante utilizado há mais de 90 anos, a SBA-15 obteve níveis semelhantes de produção de anticorpos específicos nos testes realizados. (CARVALHO, 2007, 2010; CARVALHO et al., 2010; MERCURI et al., 2006; SCARAMUZZI, 2009, 2013; SCARAMUZZI, et al., 2009).

Embora a SBA-15 demonstre um potencial para ser utilizada como adjuvante de vacinas, o modo como o sistema imunológico age na sua presença não está bem compreendido. Carvalho e colaboradores observaram em 2010, que a SBA-15 era fagocitada e que não induziu alteração na morfologia de macrófagos derivados da medula óssea de camundongos das linhagens $\mathrm{L}_{\mathrm{III}}, \mathrm{L}_{\mathrm{IV}}$ e Swiss. Em células dendríticas, derivadas da medula óssea de camundongos Balb/c, foi observado aumento na fagocitose da ovalbumina, quando essa proteína estava adsorvida em SBA-15 (SCARAMUZZI, 2013).

O fato da SBA-15 conter poros sugere que diferentes antígenos possam ficar armazenados dentro da sílica, ou formar uma malha contendo diversas partículas interligadas de sílica, protegendo o antígeno contido neste agregado molecular. A hipótese é que estes antígenos encontrados nos poros ou entre as partículas de sílica, são processados pelas células apresentadoras de antígeno que ocasionalmente fagocitam a SBA-15.

No entanto, ainda não foi realizado nenhum experimento onde seja possível ver o antígeno dentro do poro. Os testes de encapsulação executados até o momento se baseiam na dosagem de proteínas, sendo que os resultados obtidos com a produção de anticorpos contra os antígenos imunizados sugerem a encapsulação (CARVALHO et al., 2010). Outro modo de ação pode ser o efeito de depósito, um fenômeno importante para o desenvolvimento de vacinas uma vez que ocorre a liberação lenta do antígeno no local da inoculação, resultando na estimulação persistente do sistema imune, um mecanismo compartilhado com o hidróxido de alumínio (KUPFERSCHMIDT et al., 2014).

O Alum, como já citado, é utilizado desde a década de 20 e os seus mecanismos de ação ainda permanecem obscuros (GREGORIO; TRITTO; RAPPUOLI, 2008). 
Recentemente, foi descrito que a via do inflamassoma Nalp3, que resulta na ativação de caspase-1 e secreção de IL-1 $\beta$ é desencadeada in vitro, quando culturas de células recebem o estimulo de Alum (EISENBARTH et al., 2008; HORNUNG et al., 2008; KOLL et al., 2008). Mas o envolvimento de Nalp3, na atividade imunoestimuladora dos sais de alumínio, é controverso. Li et al. (2008) relataram maior produção de anticorpos $\operatorname{IgE}$ total e $\operatorname{IgG}_{1}$ específico, em animais selvagens imunizados com ovalbumina adsorvida em Alum, quando comparados com animais deficientes em Nalp3. Outros autores (FRANCHI; NÚÑES, 2008) não observaram diferenças nos níveis de $\mathrm{IgG}$, contra albumina do soro humano, em camundongos C57B/6 selvagens e deficientes de Nalp3, na presença de Alum nas formulações.

Outras partículas de sílica $\left(\mathrm{SiO}_{2}\right)$ já foram confirmadas como ativadores do inflamassoma Nalp3 (CASSEL et al., 2008; DOSTERT et al., 2008; HORNUNG et al., 2008), inclusive existem agonistas comercializados deste receptor, como no caso do $\mathrm{Nano-} \mathrm{SiO}_{2}$ (InvivoGen), sintetizado com nanopartículas de dióxido de silício. No entanto, ainda não há relatos na literatura sobre a utilização da SBA-15 como adjuvante e o envolvimento do inflamassoma em sua possível atividade imunoestimuladora.

O mecanismo de ativação de inflamassomas, especificamente NLRP3, pode ser desencadeado por diversos estímulos, dentre eles Alum e sílicas. Não parece provável que este receptor reconheça especificamente cada uma das partículas. Ao invés disso, alguns autores acreditam que ocorra desestabilização fagossomal e geração de espécies reativas do oxigênio, o que é sentido por este receptor como um sinal de perigo (CASSEL et al., 2008; DOSTERT et al., 2008; HORNUNG et al., 2008). Isso sugere que a SBA-15 fagocitada pelos macrófagos provoca a geração de sinais de perigo. Para avaliar essa hipótese, primeiramente foi testado se a capacidade endocítica dos macrófagos era necessária para a secreção de IL-1 $\beta$, e conforme observado na figura 14, a inibição da polimerização dos filamentos de actina e consequentemente da fagocitose, diminuiu drasticamente, mas não anulou a produção dessa citocina. Esse pequeno nível de IL-1 $\beta$, ainda encontrado nas culturas, pode estar relacionado ao fato de que os fagócitos podem endocitar pequenas partículas de SBA-15, enquanto que porções maiores dessa sílica são passíveis de fagocitose "frustrada" gerando a produção de espécies reativas do oxigênio (DOSTERT et al., 2008). A endocitose de partículas de sílica pode estar ocorrendo pelo reconhecimento dessas partículas por meio do receptor pertencente à classe A de receptores scavenger (SR-A), denominado MARCO (macrophage receptor with collagenous structure) (HAMILTON et al., 2006). 
Outro passo importante para compreender a interação dos macrófagos com a SBA-15 foi analisar se a produção de EROs estava envolvida na ativação do inflamassoma, por estímulos de SBA-15, e como visto na figura 15, a inibição da geração de EROs também diminuiu, mas não anulou, a produção de IL-1 $\beta$. Estudos adicionais devem ser realizados, onde possam ser inibidas simultaneamente a fagocitose e a formação de espécies reativas do oxigênio, além de outros conteúdos lisossomais, também ativadores de NLRP3, como por exemplo, catepsina B, que pode ser inibida quimicamente com CA-074 ME.

Ainda sobre os possíveis ativadores de NLRP3, sabe-se que ATP e MSU liberados para o meio extracelular, por células mortas ou danificadas podem ativar o inflamassoma NLRP3 (MARTINON et al., 2006; MARIATHASAN et al., 2006; SHI; EVANS; ROCK, 2003). Apesar dos experimentos sobre viabilidade celular (Figura 8) não demonstrarem uma morte celular significativa, com as concentrações de SBA-15 utilizadas, cerca de $7 \%$ de células mortas com $100 \mu \mathrm{g} / \mathrm{mL}$ de sílica, pode ser que essa pequena quantidade de células mortas liberem esses sinais de perigo, ATP e MSU, e assim ativem o inflamassoma NLRP3. Para descartar a hipótese do ATP é necessária a utilização de animais deficientes do receptor responsável pelo seu reconhecimento extracelular, denominado P2X7, ou um antagonista seletivo de P2X7 (A-740003) e observar se os níveis de IL-1 $\beta$ secretada, após estímulos com SBA-15, continuam os mesmos. Quanto ao MSU é preciso adicionar uricase nas culturas de macrófagos, para degradar os cristais de ácido úrico, e verificar se as culturas continuam com o mesmo padrão de secreção de IL-1 $\beta$. Todavia, Cassel e colaboradores, (2008) demonstraram que apesar de sílicas induzirem certa citotoxicidade, a liberação de IL-1 $\beta$ não era uma consequência da lise celular.

Finalizando os possíveis ativadores endógenos do inflamassoma NLRP3, o efluxo de íons potássio é descrito como um ativador deste receptor (PETRILLI et al., 2007). Dostert et al. (2008) comprovaram que algumas partículas de amianto e sílica não são internalizadas, ficam presas a superfície das células, que pode levar ao rompimento da membrana plasmática e liberação do potássio intracelular, resultando na ativação do inflamassoma NLRP3. Para certificar se o efluxo de potássio estava envolvido na liberação de IL-1 $\beta$ por estímulos de SBA-15, foram realizados alguns experimentos utilizando um tampão rico em potássio (150 mM KCl) (CASSEL et al., 2008; JIN et al., 2011), porém, não foi obtido êxito nesses experimentos, pois nas mesmas concentrações $(100-200 \mu \mathrm{g} / \mathrm{mL})$ e períodos de estímulos (1824 h) utilizados neste trabalho, as células não permaneceram viáveis, com cerca de $100 \%$ de morte em pelo menos 3 ensaios realizados (dados não mostrados). 
Como visto na figura 10 , os níveis de IL-1 $\beta$ secretada no sobrenadante da cultura de macrófagos peritoneais estimulados com SBA-15, indicam a ativação do inflamassoma de forma dependente da concentração. Essa ativação também acontece em macrófagos derivados da medula óssea de uma forma dependente de caspase-1, sendo os níveis dessa citocina restaurados na presença do inibidor de caspase-1 Z-VAD-FMK (Figura 12). Ainda assim, seria necessário a utilização de animais deficientes de caspase-1 para confirmar de outro modo essa dependência.

Também é importante a observação das proteínas pró-caspase-1, caspase-1, pró-IL-1 $\beta$ e IL-1 $\beta$ no sobrenadante e lisado das células por meio de western blotting, o que ainda é preciso ser padronizado, pois não foi obtido êxito nos experimentos realizados até o momento.

A SBA-15 demonstrou uma maior eficácia na ativação do inflamassoma quando comparado com o Hidróxido de Alumínio (IB-13/12) (Figura 11), uma vez que foi detectado mais citocina no sobrenadante da cultura que recebeu o segundo estímulo com sílica. No entanto, ainda é preciso analisar o quanto a maior produção de IL-1 $\beta$ pode ser benéfica para um adjuvante.

Os resultados da figura 13 demonstram que a SBA-15 não é reconhecida por TLRs, o que já era esperado por se tratar de um composto inorgânico. A família de receptores do tipo Toll reconhece padrões moleculares associados a patógenos, e sua identificação se iniciou com a descoberta do gene Toll de Drosophila, cuja função está relacionada no estabelecimento da polaridade dorso-ventral embrionária (HASHIMOTO; HUDSON; ANDERSON, 1988). Mais tarde, foi revelado que Toll também é essencial na defesa desses insetos contra fungos (LEMAITRE et al., 1996). Pelo menos 11 homológos de Toll já foram descritos em humanos e 13 em camundongos (KAWAI; AKIRA, 2006).

Os TLRs são glicoproteínas de membrana compostas por dois domínios, um extracelular com seqüências repetidas ricas em leucina (LRR - Leucine-richrepeat) resposnsável pelo reconhecimento de PAMPs e outro citoplasmático, com grande homologia com a região intracelular dos receptores de IL-1 (IL-1R) chamado TIR (domínio Toll/IL-1R) (AKIRA; TAKEDA, 2004). Após o reconhecimento de agonistas, a ativação dos TLRs impulsiona o recrutamento de proteínas adaptadoras como MyD88 (Myeloid Differentiation factor 88), MAL/TIRAP (MyD88-adaptor like/TIR-associated protein), TRIF (Toll-receptorassociated activator of interferon), TRAM (Toll-receptor-associated molecule) ou SARM (Sterile $\alpha$-andarmadillo-motif containing protein) que podem ativar quinases e fatores de transcrição como IRFs (IFN-responsive factors) e NF- $\mathrm{BB}$ (Nuclear fator kappa enhancer binding protein) (CARTY et al., 2006; TAKEDA; AKIRA, 2005). O NF- $\kappa \mathrm{B}$ desempenha um 
papel na expressão de genes de algumas citocinas, tais como IL-6 (LENARDO; BALTIMORE, 1989). Portanto, como a SBA-15 não induziu a produção desta citocina, mas induziu IL-1 $\beta$, é possível sugerir que este adjuvante atua pela via do inflamassoma e não pela via do NF- $\kappa \mathrm{B}$.

Todos os processos de ativação dos inflamassomas citados, até o momento, são conhecidos como convencionais ou canônicos, mas também existem relatos de ativação não canônica de inflamassomas dependentes de caspase-11, uma caspase pró-inflamatória ainda pouco estudada (AACHOUI et al., 2013; BROZ; MONACK, 2013; HAGAR et al., 2013; KAGAN, 2013; KAYAGAKI et al., 2013). Hagar et al. e também Kayagaki et al., ambos em 2013, demonstraram que essa ativação não canônica é desencadeada pelo estímulo de LPS presente no citosol das células, independentemente de TLR4. No entanto, como essa ativação não convencional ocorre ainda não é completamente compreendido.

Em experimentos de dose letal mediana (DL50), realizados utilizando duas toxinas diferentes: LPS e Toxina Diftérica, encapsulados com SBA-15, demonstraram efeitos distintos da SBA-15 em cada uma delas. Observou-se que a sílica aumentou a toxicidade do LPS e diminuiu da toxina difitérica (SANT'ANNA et al., 2013 - dados não publicados). Naquele momento não havia uma explicação obvia para o acontecido, apenas foi concluído que exotoxinas e endotoxinas agem diferentemente quando encapsuladas à SBA-15.

Agora, sabendo do reconhecimento do LPS citosólico e ativação do inflamassoma via caspase-11, podemos sugerir que o LPS presente nos poros ou entre a malha de partículas de sílica, consegue alcançar o citoplasma da célula e também ativar caspase-11, além da caspase1 ativada pela SBA-15, e isso resultaria na mortalidade de todos os animais utilizados. Podendo ser realizado os mesmos experimentos de DL50 com LPS/SBA-15 em animais deficientes para caspase-1/11 e observar se há um retardamento ou diminuição na mortalidade desses animais. Caso isso aconteça, supostamente o LPS estaria utilizando a SBA-15 para chegar ao citosol. Outra forma de demonstrar que a sílica pode transportar antígenos para o citoplasma seria a realização de experimentos semelhantes aos executados pelo grupo da Dra. Karina Bortoluci, com a utilização da flagelina purificada inserida em vesículas lipídicas catiônicas DOTAP (dioleoyl trimethylammonium propane). Este grupo demonstrou que a flagelina inserida em DOTAP é levada para o citosol ativando Naip5/Ipaf (LAGE et al., 2013).

Apesar de demonstrar a ativação de inflamassoma sobre o estímulo da SBA-15, mesmo confirmando que outros tipos de sílica ativam NLRP3, ainda não é possível afirmar que a SBA-15 ativa especificamente NLRP3. Para isso, seria imprescindível a utilização de 
animais deficientes deste receptor e também da molécula adaptadora ASC, e observar se os níveis de IL-1 $\beta$ secretada serão restaurados para o basal.

No presente trabalho, para a obtenção dos macrófagos peritoneais foi inoculado previamente, $1 \mathrm{~mL}$ de Tioglicolato 3\% na cavidade peritoneal dos animais, após quatro dias foi feito o lavado peritoneal e as células foram plaqueadas para a utilização apenas das células aderentes. Sabe-se que na cavidade peritoneal, além de macrófagos, também estão presentes muitos linfócitos $\mathrm{B}$, células dendríticas, eosinófilos, mastócitos, neutrófilos, linfócitos T, células NK e células NKT invariantes (CASSADO et al., 2011; GHOSN et al., 2010; SCHLEICHER; HESSE; BOGDAN, 2005). Sobre o estímulo prévio de Tioglicolato, Ghosn e colaboradores, (2010) demonstraram que a população da cavidade peritoneal de animais BALB/c é de aproximadamente 50\% macrófagos, $20 \%$ linfócitos B, 10\% neutrófilos, 10\% monócitos, $7 \%$ eosinófilos e cerca de $2 \%$ linfócitos T. Trabalho realizado por Schleicher; Hesse; Bogdan (2005), concluiu que em cultura de macrófagos derivados da medula óssea também existe uma pequena população de células linfóides. No entanto, nos experimentos de obtenção de MP e MDMO não foram incluídos testes para observar a porcentagem de macrófagos em cada partida de células.

Embora não analisada a porcentagem exata de macrófagos utilizados em cada experimento, os resultados obtidos, principalmente, com MDMO não podem ser subestimados. Visto que: a SBA-15 induziu níveis mais elevados de IL-1 $\beta$ quando comparado com o hidróxido de alumínio; a secreção desta citocina por estímulos da SBA-15 é dependente de caspase-1; e esta sílica atua pela via do inflamassoma e não está envolvida em outras vias de produção de citocinas, como por exemplo, IL-6. 


\section{CONCLUSÃO}

- A SBA-15 é capaz de ativar o inflamassoma de uma forma dependente da concentração;

- A SBA-15 induz níveis mais elevados de IL-1 $\beta$ quando comparada com o hidróxido de alumínio;

- A secreção de IL-1 $\beta$ por estímulos da SBA-15 é dependente de caspase-1;

- A SBA-15 atua pela via do inflamassoma e não está envolvida na via de produção de IL-6;

- A secreção de IL-1 $\beta$, por estímulos da SBA-15, é parcialmente dependente da fagocitose e da produção de Espécies Reativas do Oxigênio.

Figura 16 - Mecanismo de interação da SBA-15 com macrófagos

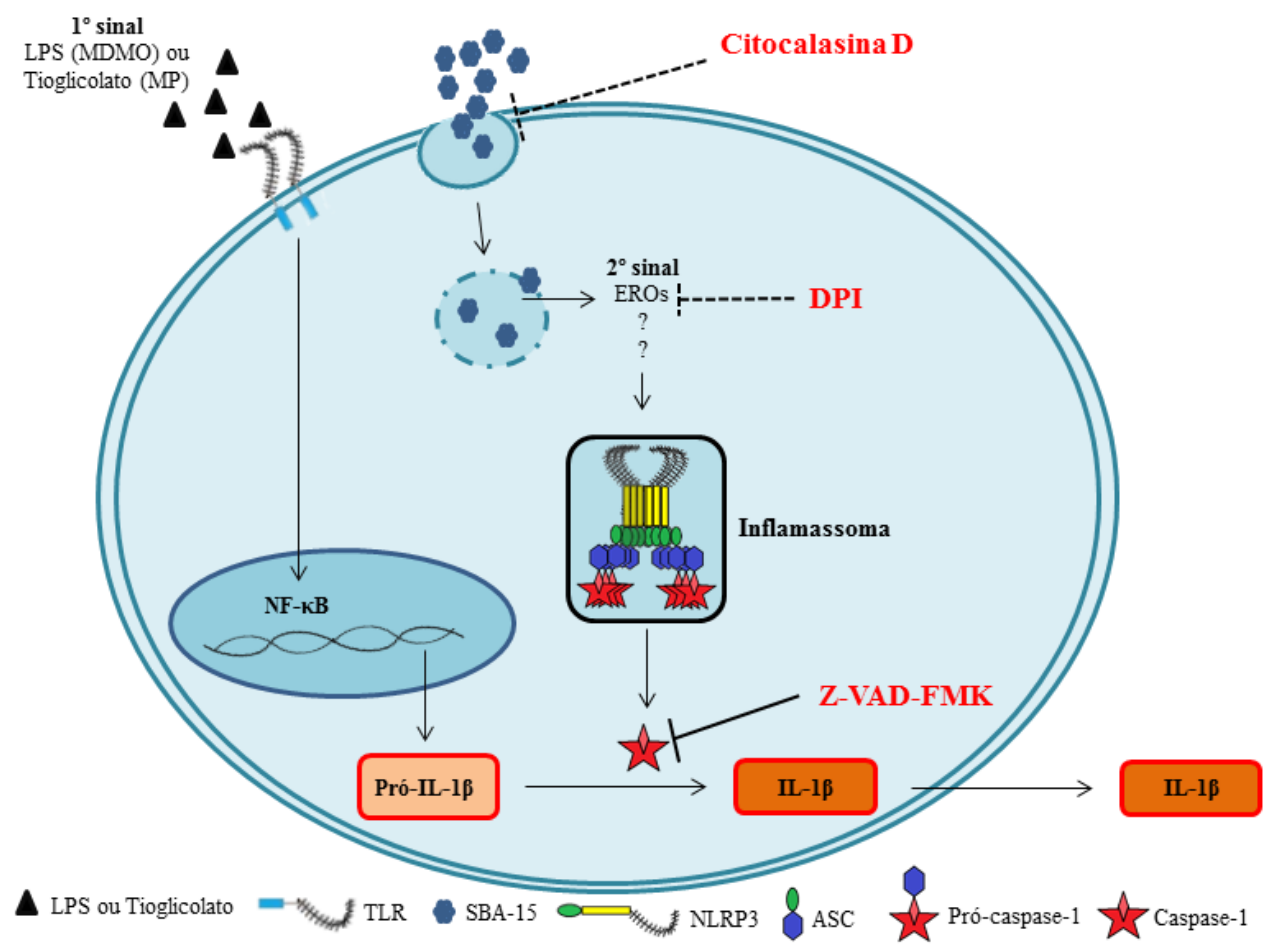

A secreção de IL-1 $\beta$ por estímulos de SBA-15 é demonstrada. Após receber o $1^{\circ}$ sinal, com LPS (MDMO) ou Tioglicolato (MP), os macrófagos produzem a forma inativa de IL-1 $\beta$ (pró-IL-1 $\beta$ ), que fica armazenada no citoplasma da célula. O $2^{\circ}$ sinal, com estímulo de SBA-15, é adicionado na cultura. A célula internaliza a SBA15 e o lisossomo se rompe liberando seu conteúdo, dentre eles, EROs, que inicia a ativação do inflamassoma NLRP3 e consequentemente da caspase-1. A caspase-1 cliva a pró-IL-1 $\beta$, para ser liberada na sua forma ativa. As inibições da fagocitose, com citocalasina $\mathrm{D}$, e das espécies reativas do oxigênio, com DPI, diminuíram consideravelmente a secreção de IL-1 $\beta$. A inibição da caspase-1, com Z-VAD-FMK, restaurou a secreção de IL$1 \beta$ para o seu estado basal. 


\section{REFERÊNCIAS*}

AACHOUI, Y. et al. Caspase-11 protects against bacteria that escape the vacuole. Science, v. 339, n. 6122, p. 975-978, 2013.

ABDALLA, Z. E. A.; LI, B.; TUFAIL, A. Direct synthesis of mesoporous (C19H42N) 4H3 (PW11O39)/SiO2 and its catalytic performance in oxidative desulfurization. Colloids and surfaces. A, Physicochemical and engineering aspects, v. 341, n. 1-3, p. 86-92, 2009.

AKIRA, S.; TAKEDA, K. Toll-like receptor signalling. Nature Reviews Immunology, v. 4, n. 7, p. 499-511, 2004.

AKIRA, S.; UEMATSU, S.; TAKEUCHI, O. Pathogen recognition and innate immunity. Cell, v. 124, n. 4, p. 783-801, 2006.

AUCOUTURIER, J.; DUPUIS, L.; GANNE, V. Adjuvants designed for veterinary and human vaccines. Vaccine, v. 19, n. 17, p. 2666-2672, 2001.

BECK, J. S. et al. A new family of mesoporous molecular sieves prepared with liquid crystal templates. Journal of the American Chemical Society, v. 114, n. 27, p. 10834-10843, 1992.

BORTOLUCI, K. R.; MEDZHITOV, R. Control of infection by pyroptosis and autophagy: role of TLR and NLR. Cellular and molecular life sciences, v. 67, n. 10, p. 1643-1651, 2010.

BRAGA, J. M. C. Pesquisa de novos adjuvantes para vacinas terapêuticas. 2011. $134 \mathrm{f}$. Tese (Doutorado em Microbiologia) - Instituto de Ciências Biomédicas, Universidade de São Paulo, São Paulo, 2011.

BROZ, P.; MONACK, D. M. Noncanonical inflammasomes: caspase-11 activation and effector mechanisms. PLoS pathogens, v. 9, n. 2, p. e1003144, 2013.

BÜRCKSTÜMMER, T. et al. An orthogonal proteomic-genomic screen identifies AIM2 as a cytoplasmic DNA sensor for the inflammasome. Nature immunology, v. 10, n. 3, p. 266272, 2009.

CARTY, M. et al. The human adaptor SARM negatively regulates adaptor protein TRIFdependent Toll-like receptor signaling. Nature immunology, v. 7, n. 10, p. 1074-1081, 2006.

CARVALHO, L. V. Estudo experimental do efeito adjuvante da sílica nanoestruturada SBA-15. 2007. 81 f. Dissertação (Mestrado em Imunologia) - Instituto de Ciências Biomédicas, Universidade de São Paulo, São Paulo, 2007.

CARVALHO, L. V. Efeito da sílica nanoestruturada SBA-15 na apresentação antigênica e na resposta imune. 2010. $88 \mathrm{f}$. Tese (Doutorado em Imunologia) - Instituto de Ciências Biomédicas, Universidade de São Paulo, São Paulo, 2010.

*De acordo com:

ASSOCIAÇÃO BRASILEIRA DE NORMASTÉCNICAS. NBR 6023: informação e documentação: referências: elaboração. Rio de Janeiro, 2002 
CARVALHO, L. V. et al. Immunological parameters related to the adjuvant effect of the ordered mesoporous silica SBA-15. Vaccine, v. 28, n. 50, p. 7829-7836, 2010.

CASSADO, A. A. et al. Cellular renewal and improvement of local cell effector activity in peritoneal cavity in response to infectious stimuli. PloS one, v. 6, n. 7, p. 22141, 2011.

CASSEL, S. L. et al. The Nalp3 inflammasome is essential for the development of silicosis. Proceedings of the National Academy of Sciences, v. 105, n. 26, p. 9035-9040, 2008.

CHAMAILLARD, M. et al. An essential role for NOD1 in host recognition of bacterial peptidoglycan containing diaminopimelic acid. Nature immunology, v. 4, n. 7, p. 702-707, 2003.

CHANG, C. et al. Nickel hexacyanoferrate multilayers on functionalized mesoporous silica supports for selective sorption and sensing of cesium. Microporous and mesoporous materials, v. 109, n. 1, p. 505-512, 2008.

COOPER, M. D.; ALDER, M. N. The evolution of adaptive immune systems. Cell, v. 124, n. 4, p. 815-822, 2006.

COX, J. C.; COULTER, A. R. Adjuvants - a classification and review of their modes of action. Vaccine, v. 15, n. 3, p. 248-256, 1997.

DOSTERT, C. et al. Innate immune activation through Nalp3 inflammasome sensing of asbestos and silica. Science Signaling, v. 320, n. 5876, p. 674, 2008.

DOSTERT, C. et al. Malarial hemozoin is a Nalp3 inflammasome activating danger signal. PloS one, v. 4, n. 8, p. e6510, 2009.

DUGAN, J. W. et al. Nucleotide oligomerization domain-2 interacts with 2'-5'-oligoadenylate synthetase type 2 and enhances RNase-L function in THP-1 cells. Molecular immunology, v. 47, n. 2, p. 560-566, 2009.

EISENBARTH, S. C. et al. Crucial role for the Nalp3 inflammasome in the immunostimulatory properties of aluminium adjuvants. Nature, v. 453, n. 7198, p. 11221126, 2008.

ELINAV, E. et al. NLRP6 inflammasome regulates colonic microbial ecology and risk for colitis. Cell, v. 145, n. 5, p. 745-757, 2011.

EVERETT, D. H. Manual of symbols and terminology for physicochemical quantities and units, Appendix II: Definitions, terminology and symbols in colloid and surface chemistry. Pure and Applied Chemistry, v. 31, n. 4, p. 577-638, 1972.

FEDEYKO, J. M.; VLACHOS, D. G.; LOBO, R. F. Understanding the differences between microporous and mesoporous synthesis through the phase behavior of silica. Microporous and mesoporous materials, v. 90, n. 1, p. 102-111, 2006.

FERNANDES-ALNEMRI, T. et al. AIM2 activates the inflammasome and cell death in response to cytoplasmic DNA. Nature, v. 458, n. 7237, p. 509-513, 2009. 
FERNANDES-ALNEMRI, T. et al. The AIM2 inflammasome is critical for innate immunity to Francisella tularensis. Nature immunology, v. 11, n. 5, p. 385-393, 2010.

FIGDOR, C. G.; VAN KOOYK, Y.; ADEMA, G. J. C-type lectin receptors on dendritic cells and Langerhans cells. Nature Reviews Immunology, v. 2, n. 2, p. 77-84, 2002.

FRANCHI, L. et al. Function of Nod-like receptors in microbial recognition and host defense. Immunological reviews, v. 227, n. 1, p. 106-128, 2009.

FRANCHI, L.; NÚÑEZ, G. The Nlrp3 inflammasome is critical for aluminium hydroxide-mediated IL- $1 \beta$ secretion but dispensable for adjuvant activity. European journal of immunology, v. 38, n. 8, p. 2085-2089, 2008.

GALLIS, K. W.; LANDRY, C. C. Synthesis of MCM-48 by a phase transformation process. Chemistry of materials, v. 9, n. 10, p. 2035-2038, 1997.

GARCIA, P. R. A. F. Síntese e análise da sílica mesoporosa SBA-15 para incorporação de moléculas. 2015. Dissertação de Mestrado. Universidade de São Paulo.

GHOSN, E. E. B. et al. Two physically, functionally, and developmentally distinct peritoneal macrophage subsets. Proceedings of the National Academy of Sciences, v. 107, n. 6, p. 2568-2573, 2010.

GIRARDIN, S. E. et al. Nod1 detects a unique muropeptide from gram-negative bacterial peptidoglycan. Science, v. 300, n. 5625, p. 1584-1587, 2003 a.

GIRARDIN, S. E. et al. Nod2 is a general sensor of peptidoglycan through muramyl dipeptide (MDP) detection. Journal of Biological Chemistry, v. 278, n. 11, p. 8869-8872, 2003 b.

GREGORIO, E.; TRITTO, E.; RAPPUOLI, R. Alum adjuvanticity: unraveling a century old mystery. European journal of immunology, v. 38, n. 8, p. 2068-2071, 2008.

GUPTA, R. K. et al. Adjuvants - a balance between toxicity and adjuvanticity. Vaccine, v. 11, n. 3, p. 293-306, 1993.

GUPTA, R. K.; SIBER, G. R. Adjuvants for human vaccines-current status, problems and future prospects. Vaccine, v. 13, n. 14, p. 1263-1276, 1995.

HAGAR, J. A. et al. Cytoplasmic LPS activates caspase-11: implications in TLR4independent endotoxic shock. Science, v. 341, n. 6151, p. 1250-1253, 2013.

HALFF, E. F. et al. Formation and structure of a NAIP5-NLRC4 inflammasome induced by direct interactions with conserved $\mathrm{N}$-and $\mathrm{C}$-terminal regions of flagellin. Journal of Biological Chemistry, v. 287, n. 46, p. 38460-38472, 2012.

HAMILTON, R. F. et al. MARCO mediates silica uptake and toxicity in alveolar macrophages from C57BL/6 mice. Journal of Biological Chemistry, v. 281, n. 45, p. 3421834226, 2006.

HASHIMOTO, C.; HUDSON, K. L.; ANDERSON, K. V. The Toll gene of drosophila, required for dorsal-ventral embryonic polarity, appears to encode a transmembrane protein. Cell, v. 52, n. 2, p. 269-279, 1988. 
HORNUNG, V. et al. Silica crystals and aluminum salts activate the NALP3 inflammasome through phagosomal destabilization. Nature immunology, v. 9, n. 8, p. 847-856, 2008.

HORNUNG, V. et al. AIM2 recognizes cytosolic dsDNA and forms a caspase-1-activating inflammasome with ASC. Nature, v. 458, n. 7237, p. 514-518, 2009.

INOHARA, N. et al. Nod1, an Apaf-1-like activator of caspase-9 and nuclear factor- $\kappa B$. Journal of Biological Chemistry, v. 274, n. 21, p. 14560-14567, 1999.

INOHARA, N. et al. Human Nod1 confers responsiveness to bacterial lipopolysaccharides. Journal of Biological Chemistry, v. 276, n. 4, p. 2551-2554, 2001.

INOHARA, $\mathrm{N}$. et al. NOD-LRR proteins: role in host-microbial interactions and inflammatory disease. Annu. Rev. Biochem., v. 74, p. 355-383, 2005.

INVIVOGEN. Nod-Like Receptors Review. Disponível em: < http://www.invivogen.com/review-nlr>. Acesso em: 15 nov. 2014.

JANEWAY, C. A. Approaching the asymptote? Evolution and revolution in immunology. In: Cold Spring Harbor symposia on quantitative biology. Cold Spring Harbor Laboratory Press, 1989. p. 1-13.

JANEWAY, C. A.; MEDZHITOV, R. Innate immune recognition. Annual review of immunology, v. 20, n. 1, p. 197-216, 2002.

JANSEN, T. et al. Structure-activity relations of water-in-oil vaccine formulations and induced antigen-specific antibody responses. Vaccine, v. 23, n. 8, p. 1053-1060, 2005.

JIN, C. et al. NLRP3 inflammasome plays a critical role in the pathogenesis of hydroxyapatite-associated arthropathy. Proceedings of the National Academy of Sciences, v. 108, n. 36, p. 14867-14872, 2011.

KAGAN, J. C. Sensing Endotoxins from Within. Science (New York, NY), v. 341, n. 6151, p. 1184, 2013.

KANNEGANTI, T. D. et al. Bacterial RNA and small antiviral compounds activate caspase-1 through cryopyrin/Nalp3. Nature, v. 440, n. 7081, p. 233-236, 2006

KANNEGANTI, T. D. et al. Intracellular NOD-like receptors in host defense and disease. Immunity, v. 27, n. 4, p. 549, 2007.

KAWAI, T.; AKIRA, S. TLR signaling. Cell Death \& Differentiation, v. 13, n. 5, p. 816$825,2006$.

KAYAGAKI, N. et al. Noncanonical inflammasome activation by intracellular LPS independent of TLR4. Science, v. 341, n. 6151, p. 1246-1249, 2013.

KIM, J. M.; JUN, S.; RYOO, R. Improvement of hydrothermal stability of mesoporous silica using salts: reinvestigation for time-dependent effects. The Journal of Physical Chemistry B, v. 103, n. 30, p. 6200-6205, 1999. 
KOOL, M. et al. Cutting edge: alum adjuvant stimulates inflammatory dendritic cells through activation of the NALP3 inflammasome. The Journal of Immunology, v. 181, n. 6, p. 37553759, 2008.

KRESGE, C. T. et al. Ordered mesoporous molecular sieves synthesized by a liquid-crystal template mechanism. Nature, v. 359, n. 6397, p. 710-712, 1992.

KRESGE, C. T.; ROTH, W. J. The discovery of mesoporous molecular sieves from the twenty year perspective. Chemical Society Reviews, v. 42, n. 9, p. 3663-3670, 2013.

KUPFERSCHMIDT, N. et al. Mesoporous silica particles potentiate antigen-specific T-cell responses. Nanomedicine, p. 1-12, 2014.

LAGE, S. L. et al. Cytosolic flagellin-induced lysosomal pathway regulates inflammasomedependent and-independent macrophage responses. Proceedings of the National Academy of Sciences, v. 110, n. 35, p. E3321-E3330, 2013.

LAMKANFI, M.; MALIREDDI, RK S.; KANNEGANTI, T. Fungal zymosan and mannan activate the cryopyrin inflammasome. Journal of Biological Chemistry, v. 284, n. 31, p. 20574-20581, 2009.

LEMAITRE, B. et al. The Dorsoventral Regulatory Gene Cassette spätzle/Toll/cactus Controls the Potent Antifungal Response in Drosophila Adults. Cell, v. 86, n. 6, p. 973-983, 1996.

LENARDO, M. J.; BALTIMORE, D. NF- $\mathrm{BB}$ : a pleiotropic mediator of inducible and tissuespecific gene control. Cell, v. 58, n. 2, p. 227-229, 1989.

LI, H. et al. Cutting edge: inflammasome activation by alum and alum's adjuvant effect are mediated by NLRP3. The Journal of Immunology, v. 181, n. 1, p. 17-21, 2008.

LIGHTFIELD, K. L. et al. Critical function for Naip5 in inflammasome activation by a conserved carboxy-terminal domain of flagellin. Nature immunology, v. 9, n. 10, p. 11711178, 2008.

LIGHTFIELD, K. L. et al. Differential requirements for NAIP5 in activation of the NLRC4 inflammasome. Infection and immunity, v. 79, n. 4, p. 1606-1614, 2011.

LUPFER, C. et al. Receptor interacting protein kinase 2-mediated mitophagy regulates inflammasome activation during virus infection. Nature immunology, v. 14, n. 5, p. 480-488, 2013.

MARIATHASAN, S. et al. Cryopyrin activates the inflammasome in response to toxins and ATP. Nature, v. 440, n. 7081, p. 228-232, 2006.

MARIATHASAN, S. ASC, Ipaf and Cryopyrin/Nalp3: bona fide intracellular adapters of the caspase-1 inflammasome. Microbes and infection, v. 9, n. 5, p. 664-671, 2007.

MARINA-GARCÍA, N. et al. Pannexin-1-mediated intracellular delivery of muramyl dipeptide induces caspase-1 activation via cryopyrin/NLRP3 independently of Nod2. The Journal of Immunology, v. 180, n. 6, p. 4050-4057, 2008. 
MARTINON, F. et al. Identification of bacterial muramyl dipeptide as activator of the NALP3/cryopyrin inflammasome. Current Biology, v. 14, n. 21, p. 1929-1934, 2004.

MARTINON, F; TSCHOPP, J. NLRs join TLRs as innate sensors of pathogens. Trends in immunology, v. 26, n. 8, p. 447-454, 2005.

MARTINON, F. et al. Gout-associated uric acid crystals activate the NALP3 inflammasome. Nature, v. 440, n. 7081, p. 237-241, 2006.

MARTINON, F.; TSCHOPP, J. Inflammatory caspases and inflammasomes: master switches of inflammation. Cell Death \& Differentiation, v. 14, n. 1, p. 10-22, 2006.

MARTINON, F.; MAYOR, A.; TSCHOPP, J. The inflammasomes: guardians of the body. Annual review of immunology, v. 27, p. 229-265, 2009.

MATOS, J. R. et al. Toward the synthesis of extra-large-pore MCM-41 analogues. Chemistry of materials, v. 13, n. 5, p. 1726-1731, 2001.

MATZINGER, P. The danger model: a renewed sense of self. Science, v. 296, n. 5566, p. 301-305, 2002.

MEDZHITOV, R; JANEWAY, C. A. Innate immunity: the virtues of a nonclonal system of recognition. Cell, v. 91, n. 3, p. 295-298, 1997.

MERCURI, L. P. et al. Ordered Mesoporous Silica SBA-15: A New Effective Adjuvant to Induce Antibody Response. Small, v. 2, n. 2, p. 254-256, 2006.

MIYAJI, E. N. et al. Trends in adjuvant development for vaccines: DAMPs and PAMPs as potential new adjuvants. Brazilian journal of medical and biological research, v. 44, n. 6 , p. 500-513, 2011.

MOGENSEN, T. H. Pathogen recognition and inflammatory signaling in innate immune defenses. Clinical microbiology reviews, v. 22, n. 2, p. 240-273, 2009.

MOSMANN, T. Rapid colorimetric assay for cellular growth and survival: application to proliferation and cytotoxicity assays. Journal of immunological methods, v. 65, n. 1, p. 5563, 1983.

MURUVE, D. A. et al. The inflammasome recognizes cytosolic microbial and host DNA and triggers an innate immune response. Nature, v. 452, n. 7183, p. 103-107, 2008.

NETO, F. M. Potencial de Aplicação de Sílica Mesoporosa Ordenada em transporte, proteção e liberação de fármacos. 2013. Tese de Doutorado. Universidade de São Paulo.

NOUR, A. M. et al. Anthrax lethal toxin triggers the formation of a membrane-associated inflammasome complex in murine macrophages. Infection and immunity, v. 77, n. 3, p. 1262-1271, 2009.

OGURA, Y. et al. Nod2, a Nod1/Apaf-1 family member that is restricted to monocytes and activates NF-кB. Journal of Biological Chemistry, v. 276, n. 7, p. 4812-4818, 2001. 
OGURA, Y.; SUTTERWALA, F. S.; FLAVELL, R. A. The inflammasome: first line of the immune response to cell stress. Cell, v. 126, n. 4, p. 659-662, 2006.

OOI, Y.; BHATIA, S. Aluminum-containing SBA-15 as cracking catalyst for the production of biofuel from waste used palm oil. Microporous and mesoporous materials, v. 102, n. 1, p. 310-317, 2007.

OTT, G.; NEST, G. V. Development of vaccine adjuvants: a historical perspective. Vaccine Adjuvants and Delivery Systems, p. 1-31, 2007.

PASQUA, L. et al. Recent development, applications, and perspectives of mesoporous silica particles in medicine and biotechnology. Current medicinal chemistry, v. 16, n. 23, p. 30543063, 2009.

PETRILLI, V. et al. Activation of the NALP3 inflammasome is triggered by low intracellular potassium concentration. Cell Death \& Differentiation, v. 14, n. 9, p. 1583-1589, 2007.

PETROVSKY, N.; AGUILAR, J. C. Vaccine adjuvants: current state and future trends. Immunology and cell biology, v. 82, n. 5, p. 488-496, 2004.

POLLOCK, R. A. et al. Size and spatial distribution of micropores in SBA-15 using CMSANS. Chemistry of Materials, v. 23, n. 17, p. 3828-3840, 2011.

RAHMAT, N.; ABDULlAH, A. Z.; MOHAMED, A. R. A review: mesoporous Santa Barbara amorphous-15, types, synthesis and its applications towards biorefinery production. American Journal of Applied Sciences, v. 7, n. 12, p. 1579, 2010.

RATHINAM, V. A. K et al. The AIM2 inflammasome is essential for host defense against cytosolic bacteria and DNA viruses. Nature immunology, v. 11, n. 5, p. 395-402, 2010.

RESENDE, F. C. R. et al. Adjuvantes de vacinas: possibilidades de uso em seres humanos ou animais. Rev. bras. alerg. imunopatol., v. 27, p. 116-124, 2004.

ROBERTS, T. L. et al. HIN-200 proteins regulate caspase activation in response to foreign cytoplasmic DNA. Science, v. 323, n. 5917, p. 1057-1060, 2009.

SANT'ANNA, O. A. et al. Genetic parameters of the polygenic regulation of antibody responsiveness to flagellar and somatic antigens of salmonellae. International Journal of Immunogenetics, v. 9, n. 3, p. 191-205, 1982.

SCARAMUZZI, K. Efeito adjuvante da sílica mesoporosa nanoestruturada SBA-15 na imunização pela via oral. 2009. 74 f. Dissertação (Mestrado em Imunologia) - Instituto de Ciências Biomédicas, Universidade de São Paulo, São Paulo, 2009.

SCARAMUZZI, K. Investigação dos mecanismos de ação da sílica mesoporosa Nanoestruturada SBA-15 como adjuvante. 2013. 161 f. Tese (Doutorado em Imunologia) Instituto de Ciências Biomédicas, Universidade de São Paulo, São Paulo, 2013.

SCARAMUZZI, K. et al. Uma história contada no futuro: complexo imunogênico constituído por antígenos vacinais adsorvidos/encapsulados em sílica mesoporosa nanoestruturada. Cadernos de História da Ciência, v. 5, n. 2, p. 57-66, 2009. 
SCARAMUZZI, K. et al. Nanostructured SBA-15 silica as an adjuvant in immunization with hepatitis B vaccine einstein. Einstein, v. 9, p. 436-441, 2011.

SCHLEICHER, U.; HESSE, A.; BOGDAN, C. Minute numbers of contaminant CD8+ T cells or CD11b+ CD11c+ NK cells are the source of IFN- $\gamma$ in IL-12/IL-18-stimulated mouse macrophage populations. Blood, v. 105, n. 3, p. 1319-1328, 2005.

SCHRODER, K.; TSCHOPP, J. The inflammasomes. Cell, v. 140, n. 6, p. 821-832, 2010.

SEFTEL, E. M. et al. Synthesis and characterization of catalytic metal semiconductor-doped siliceous materials with ordered structure for chemical sensoring. Journal of porous materials, v. 20, n. 5, p. 1119-1128, 2013.

SHI, Y.; EVANS, J. E.; ROCK, K. L. Molecular identification of a danger signal that alerts the immune system to dying cells. Nature, v. 425, n. 6957, p. 516-521, 2003.

SHIO, M. T. et al. Malarial hemozoin activates the NLRP3 inflammasome through Lyn and Syk kinases. PLoS pathogens, v. 5, n. 8, p. 1-14, 2009.

SOUZA, A. Híbridos de Gel Polimérico em Sílica Mesoporosa Estruturalmente Ordenada para Liberação Controlada de Fármacos. 2009. 159 f. Dissertação (Mestrado em Engenharia Química) - Escola de Engenharia, Universidade Federal de Minas Gerais, Minas Gerais, 2009.

SUTTERWALA, F. S. et al. Critical role for NALP3/CIAS1/Cryopyrin in innate and adaptive immunity through its regulation of caspase-1.Immunity, v. 24, n. 3, p. 317-327, 2006.

TAGUCHI, A.; SCHÜTH, F. Ordered mesoporous materials in catalysis. Microporous and Mesoporous Materials, v. 77, n. 1, p. 1-45, 2005.

TAKEDA, K.; AKIRA, S. Toll-like receptors in innate immunity. International immunology, v. 17, n. 1, p. 1-14, 2005.

TAKEUCHI, O; AKIRA, S. Pattern recognition receptors and inflammation. Cell, v. 140, n. 6, p. 805-820, 2010.

TING, J. P.Y. et al. The NLR gene family: an official nomenclature. Immunity, v. 28, n. 3, p. $285,2008$.

$\mathrm{XU}, \mathrm{X}$. et al. Laccase immobilized on methylene blue modified mesoporous silica MCM41/PVA. Materials Science and Engineering: C, v. 29, n. 7, p. 2160-2164, 2009.

YANAGISAWA, T. et al. The preparation of alkyltrimethylammonium-kanemite complexes and their conversion to microporous materials. Bull. Chem. Soc. Jpn, v. 63, n. 4, p. 988-992, 1990.

YANG, H.; COOMBS, N.; OZIN, G. A. Morphogenesis of shapes and surface patterns in mesoporous silica. Nature, v. 386, n. 6626, p. 692-695, 1997.

ZHAO, D. et al. Triblock copolymer syntheses of mesoporous silica with periodic 50 to 300 angstrom pores. Science, v. 279, n. 5350, p. 548-552, 1998a. 
ZHAO, D. et al. Nonionic triblock and star diblock copolymer and oligomeric surfactant syntheses of highly ordered, hydrothermally stable, mesoporous silica structures. Journal of the American Chemical Society, v. 120, n. 24, p. 6024-6036, 1998b.

ZORNOZA, B. et al. Mesoporous silica sphere- polysulfone mixed matrix membranes for gas separation. Langmuir, v. 25, n. 10, p. 5903-5909, 2009. 